\title{
Structure of the Northern Moine Fthrust zone, Loch Eriboll, Scottish Caledonides
}

\section{Mike Searle}

mike.searle@earth.ox.ac.uk

Sam B. Cornish

Andrew Heard

John-Henry Charles

Joshua Branch

Dept. Earth Sciences, Oxford University, South Parks Road, OX1 3AN, United Kingdom of Great Britain and Northern Ireland

${ }^{*}$ Corresponding author.

"Submitted to: Tectonophysics Special volume "Style of deformation and tectono-sedimentary evolution of fold-and-thrust belts and foreland basins".

\section{Abstract}

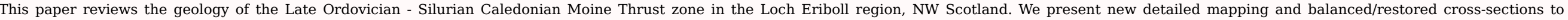

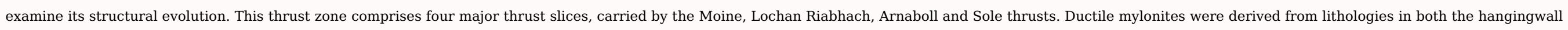

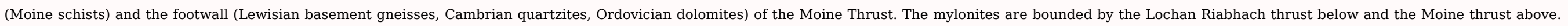

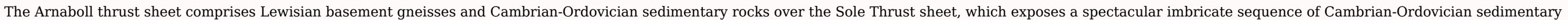

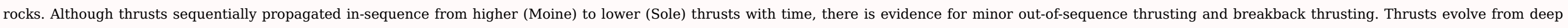

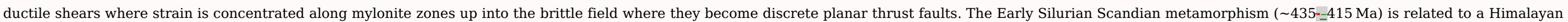

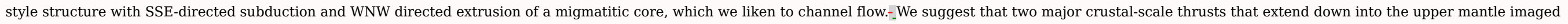
on seismic profiles across the foreland, the Outer Isles and Flannan thrusts, are unrelated spatially or temporally to the Moine thrust sequence.

Keywords: Moine thrust; Caledonian orogeny; 正old-thrust belt

\subsection{Introduction}

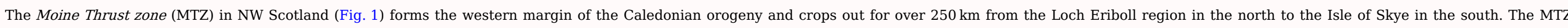

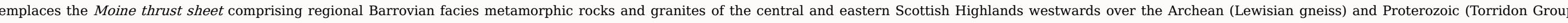

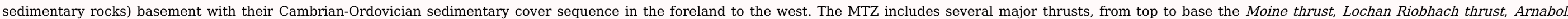

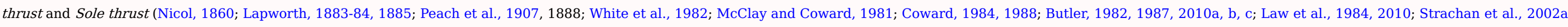

b (omit 'a'); British Geological Survey, 2002; Holdsworth et al., 2006, 2007; White, 2010; Thigpen et al., 2010a, b) 


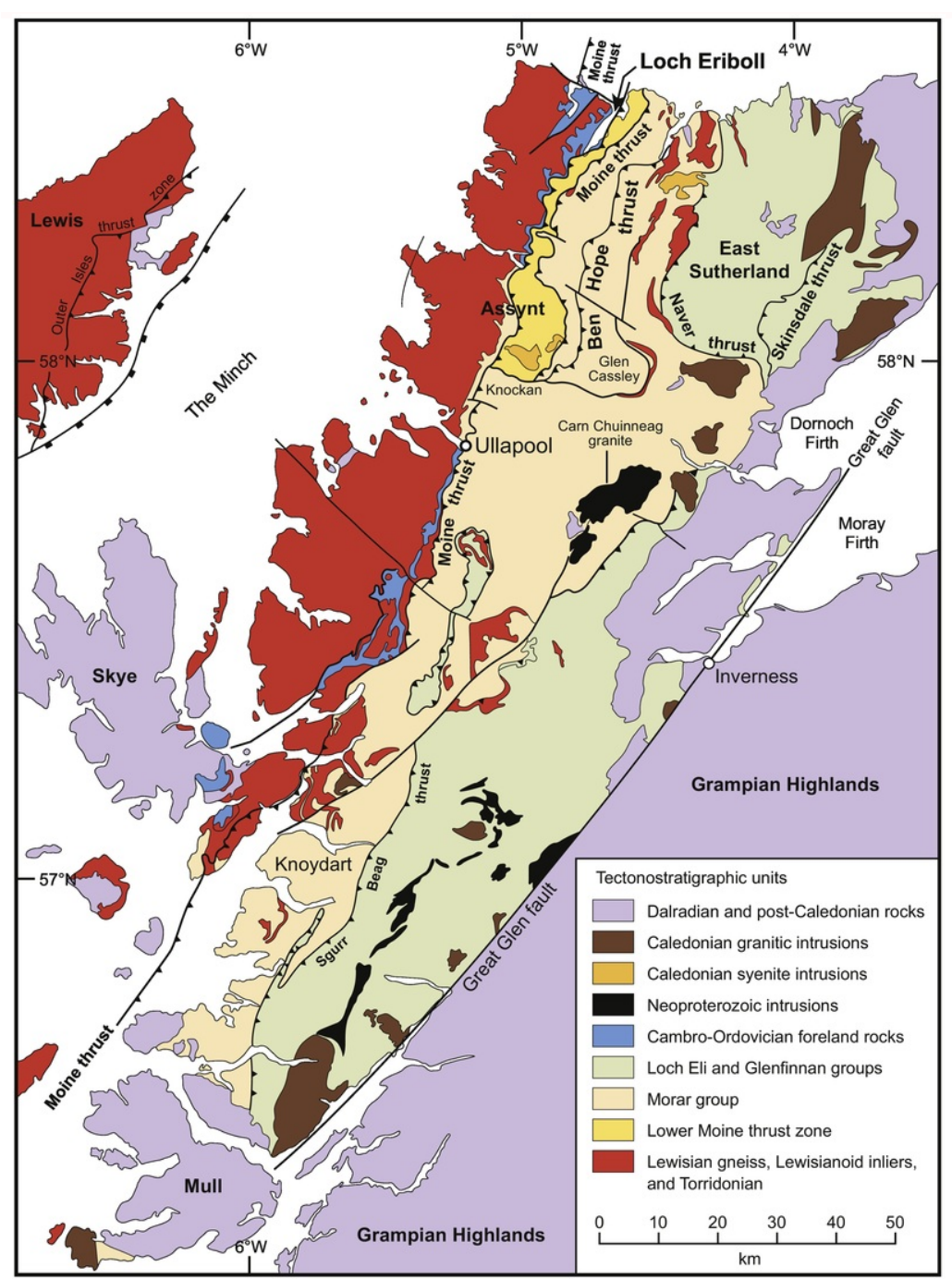

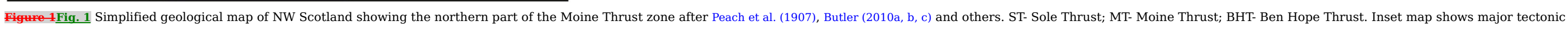
zones of Scotland; GGF - Great Glen Fault; HBF - Highland Boundary Fault; SUF - Southern Uplands Fault.

alt-text: Fig. 1

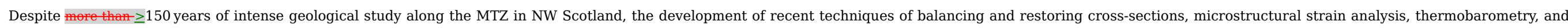

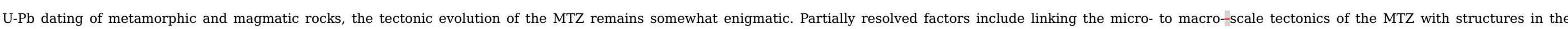

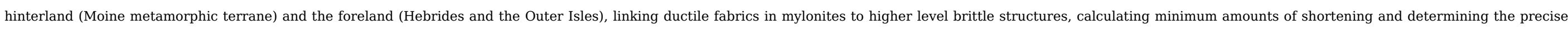
sequence of thrusting. Excellent summaries of the history of ideas relating to the MTZ can be found in Law et al. (2010) and Butler (2010a, b).

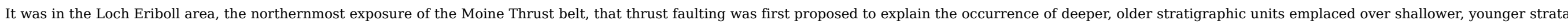

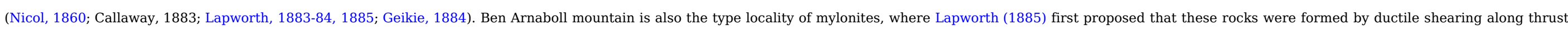




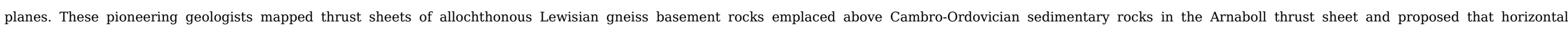

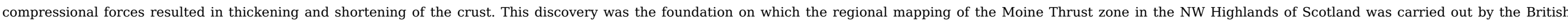

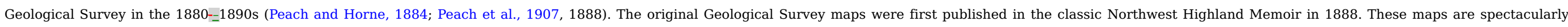
accurate and repeated studies have not found major flaws in their mapping.

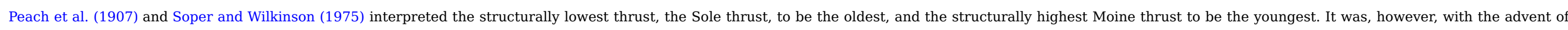

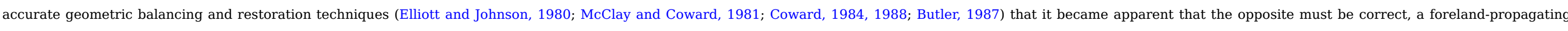

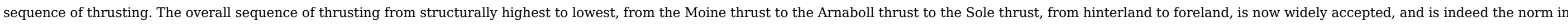
most mountain belts.

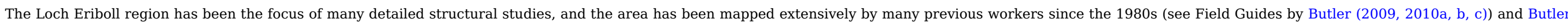

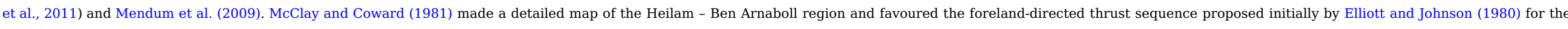

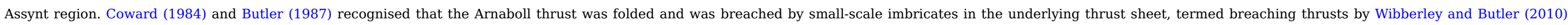

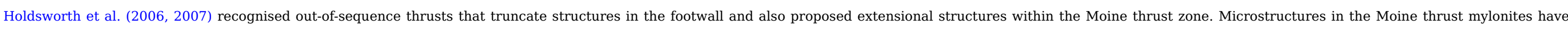

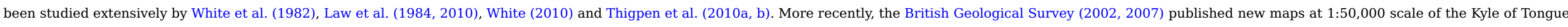

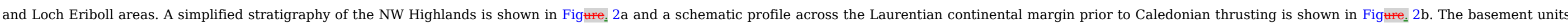

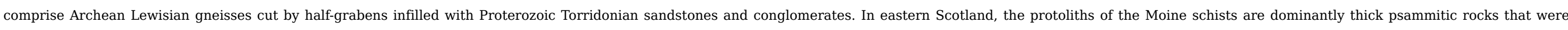

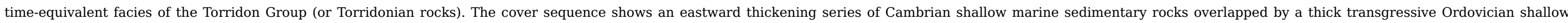
marine dolomite (Durness Group).

$$
\text { WEST }
$$

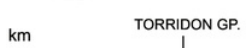

EAST

$\mathrm{km}$
0
20
40

(a)
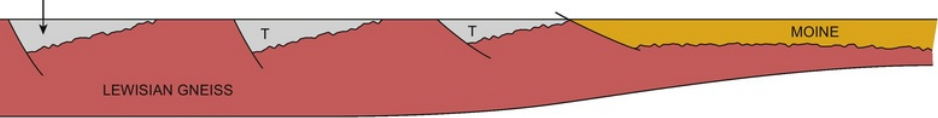

WEST

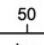
100

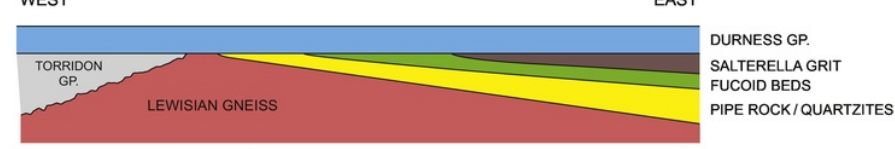

(b)

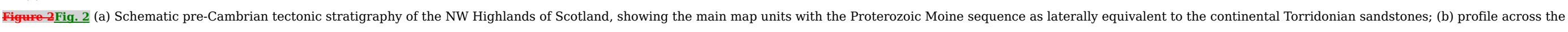

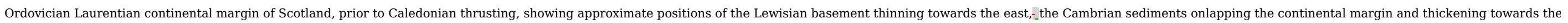
east, and the Ordovician Durness Group limestones and dolomites unconformably onlapping and covering all lower units.

\section{alt-text: Fig. 2}

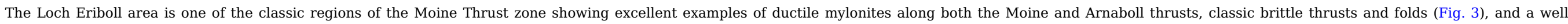

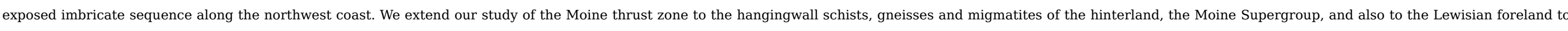
the west. Post-Caledonian normal faults have down-faulted the Moine Thrust zone rocks to the west allowing further constraints on the westward extension of the thrust sheets. 


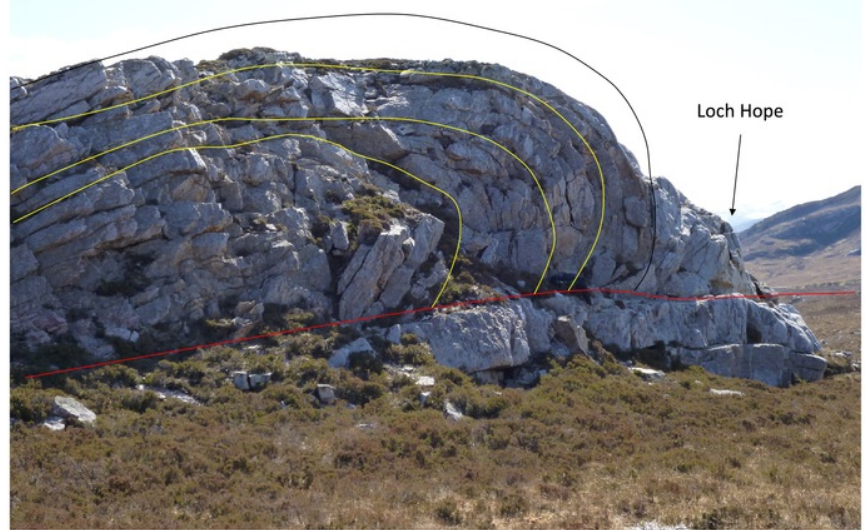

Figure 3Fiq. 3 Photograph of a small-scale west-verging thrust with hangingwall anticline in Cambrian quartzites (Pipe Rock) at Ben Heilam, Loch Eriboll region.

alt-text: Fig. 3

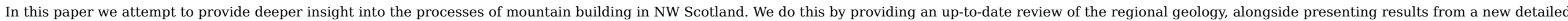

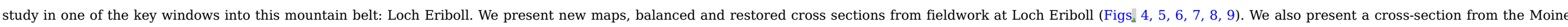

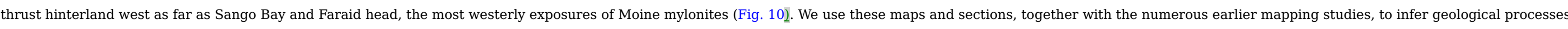

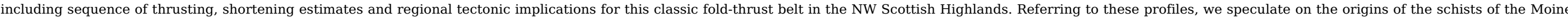

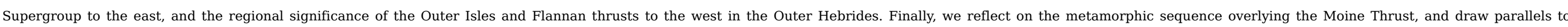
Himalayan style orogenesis. 


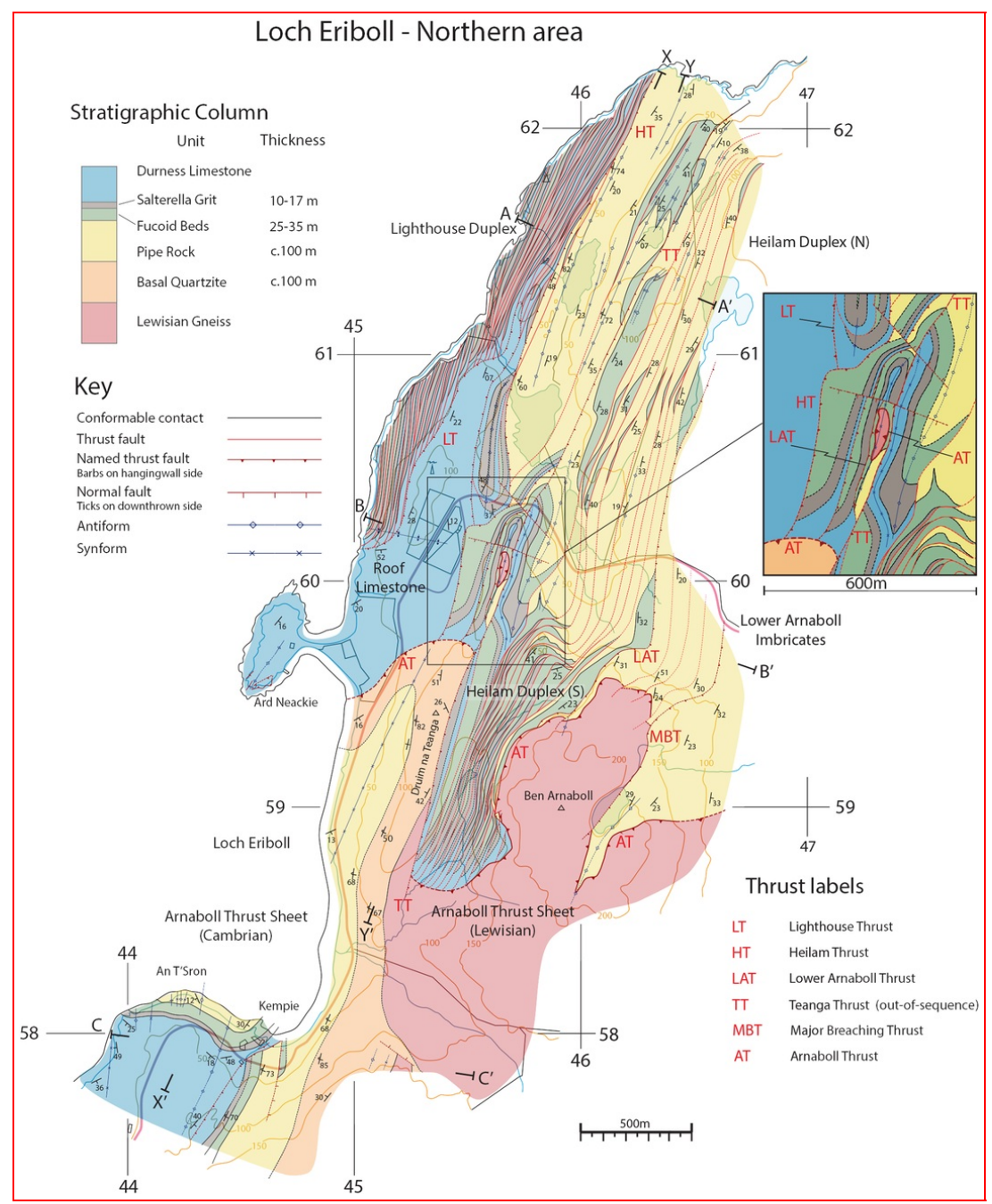

Figure-4Fig. 4 Geological map of the Moine Thrust zone in the Loch Eriboll area showing lines of cross-sections in Figmess. 5 and 6. alt-text: Fig. 4 


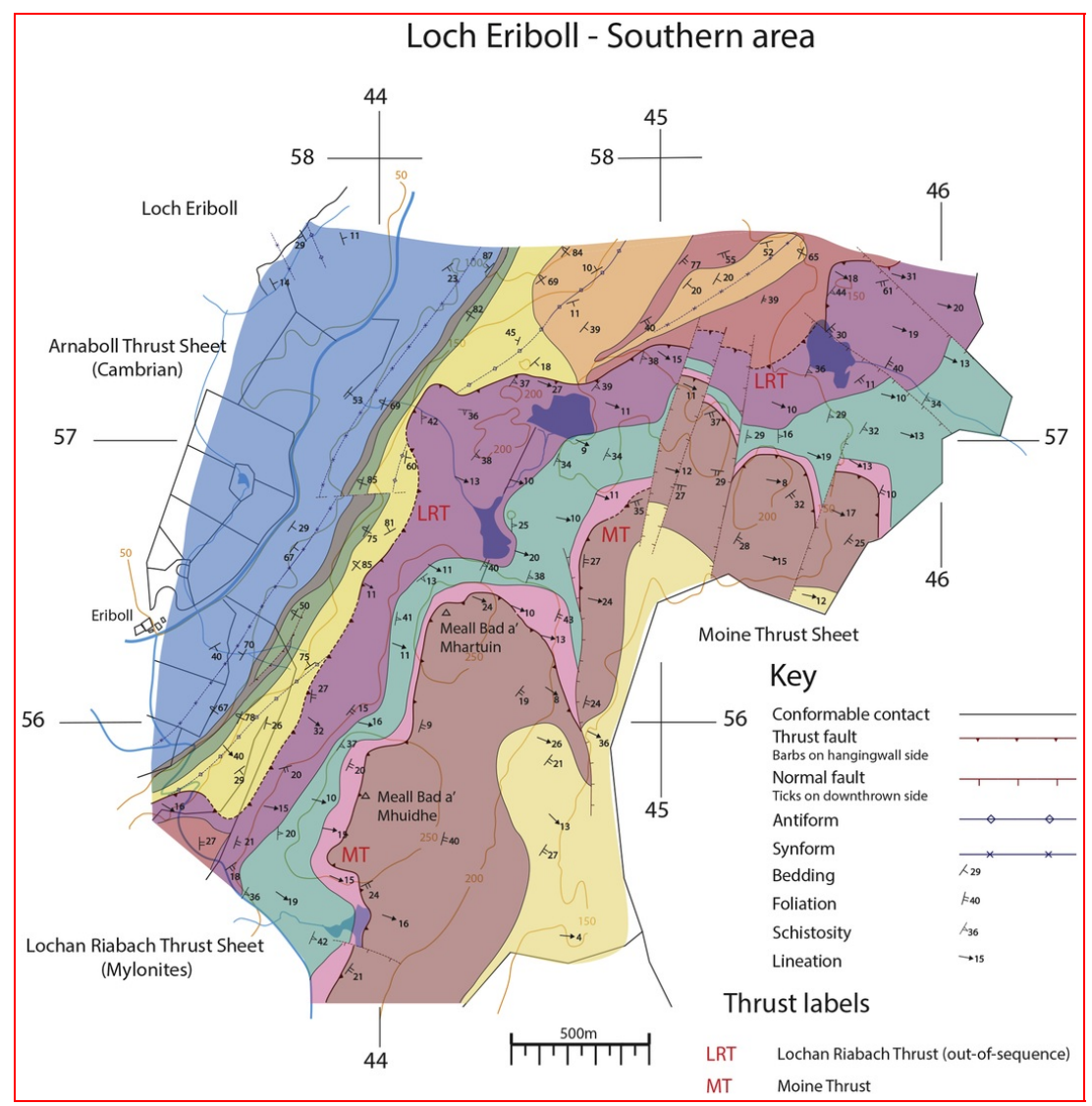

Figure 5 Fig. 5 Geological map of the southern part of the Loch Eriboll area with balanced cross-section A-A alt-text: Fig. 5 


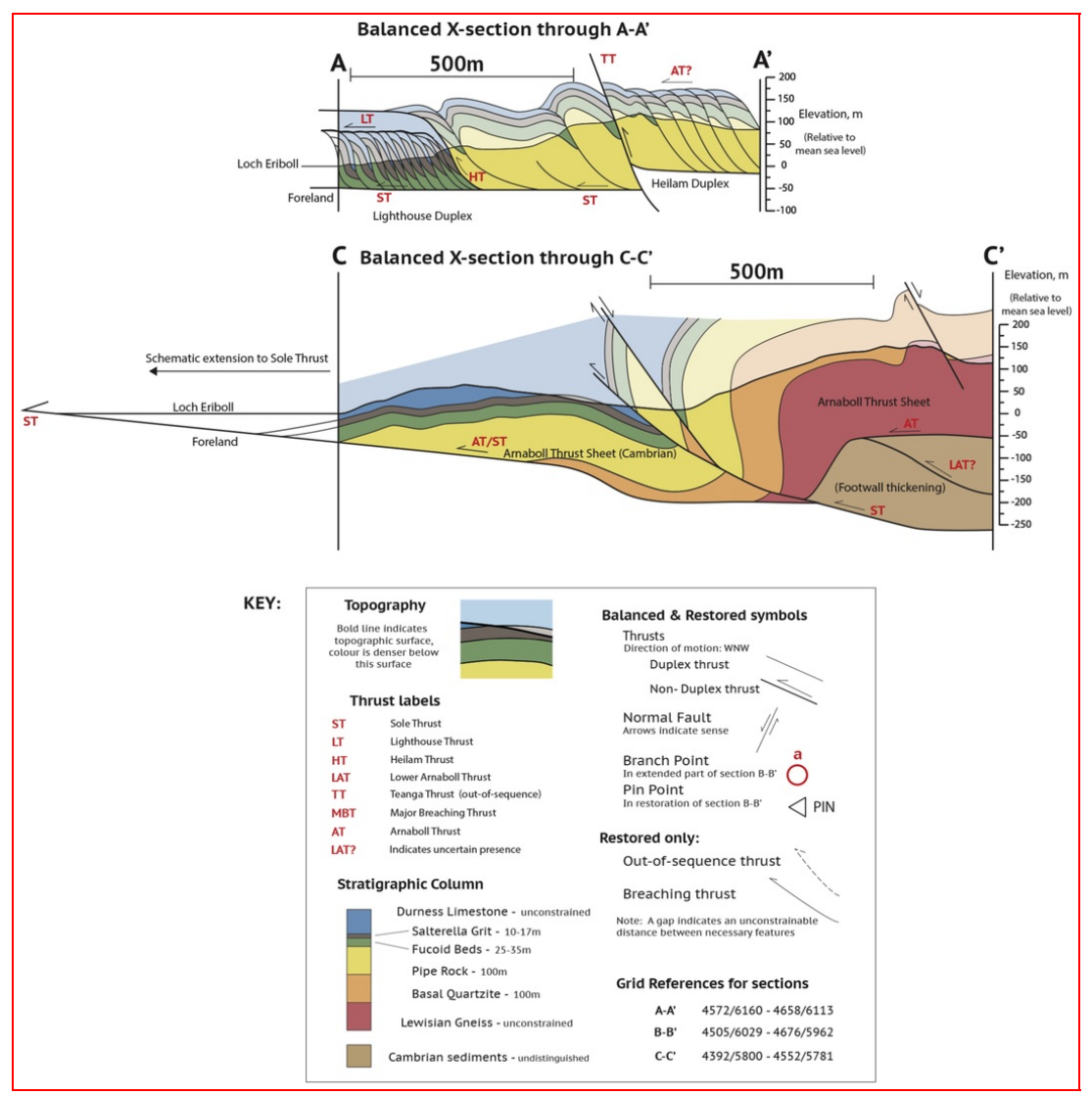

Figure 6 Balanced cross-sections A-A and C-C alt-text: Fig. 6
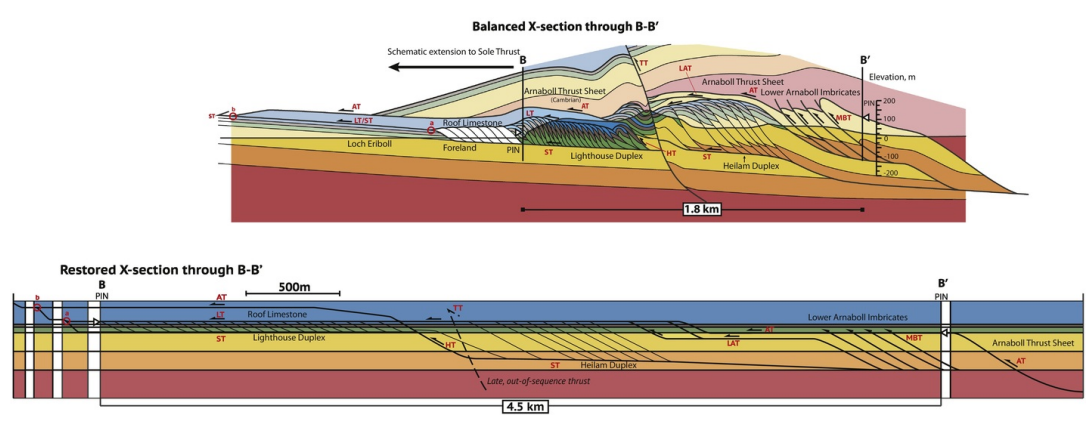

Figure 7.Fig. 7 Balanced and restored cross-section B-B" across the northern part of the Loch Eriboll area. See Fig. 4 for line of section. Key is as per Fig. 4. alt-text: Fig. 7 


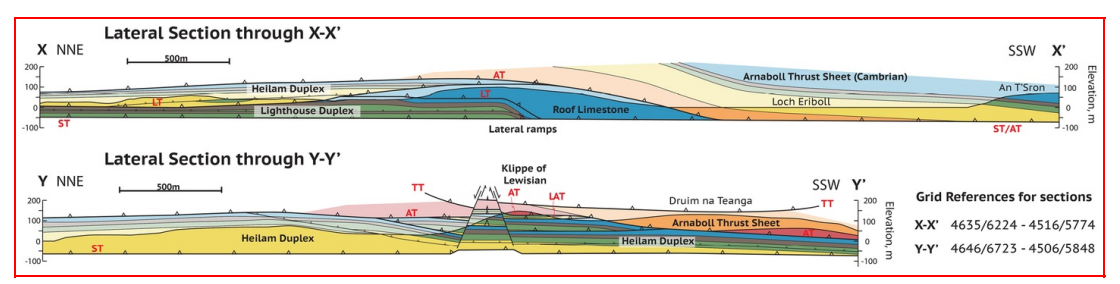

Figure 8.Fig. 8 Lateral sections X-X $\mathrm{X}$ and YYY through the northern part of the Loch Eriboll area. See Fig. 4 for line of section. Key is as per Fig. 4.

alt-text: Fig. 8

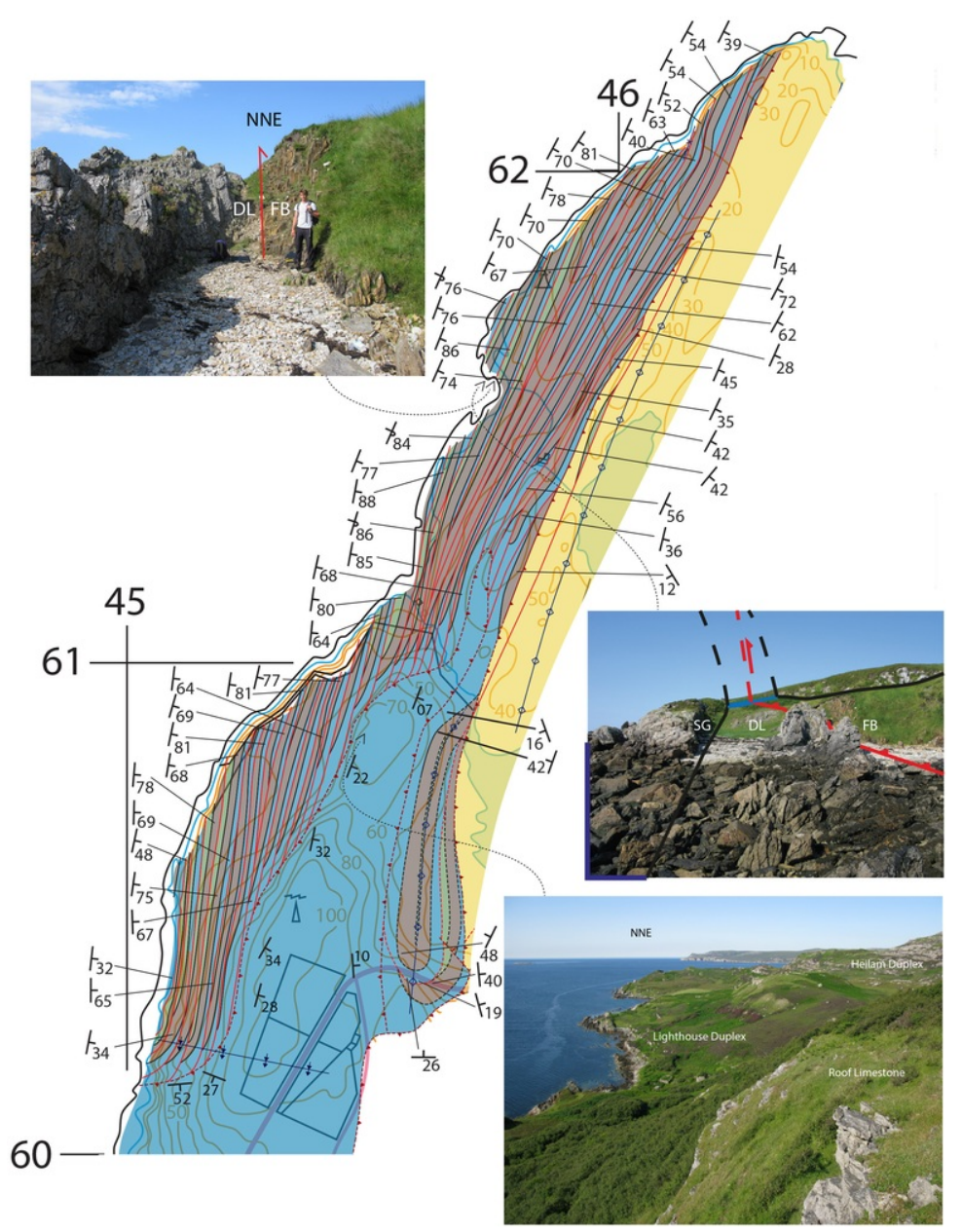

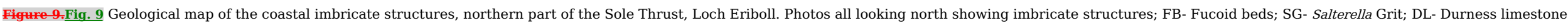
alt-text: Fig. 9 


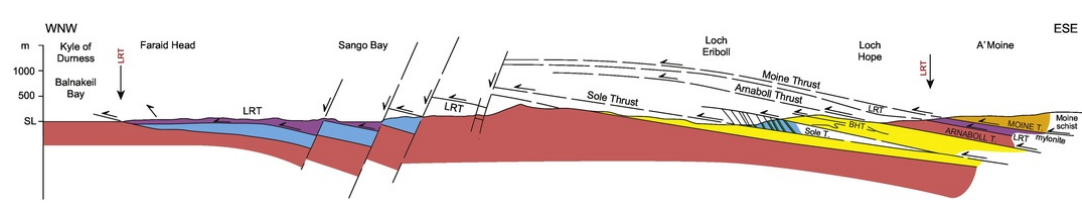

Figure 10-Fiq. 10 Cross-section of the Moine thrust zone from the Kyle of Durness and Faraid Head to Loch Eriboll and A:Moine. alt-text: Fig. 10

\subsection{Regional Ttectonic setting}

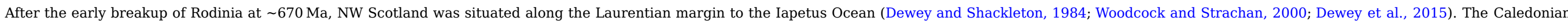

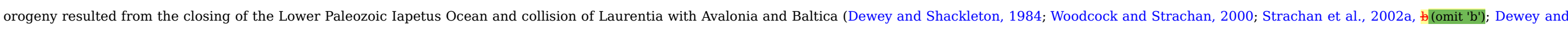

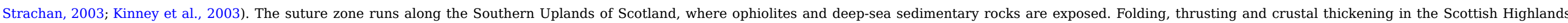

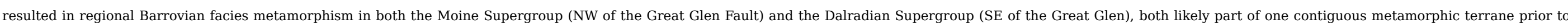

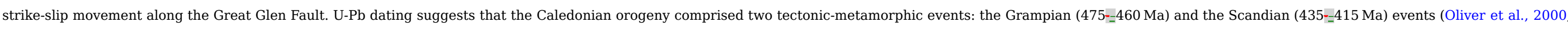

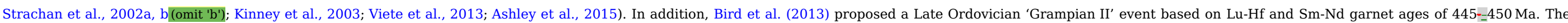

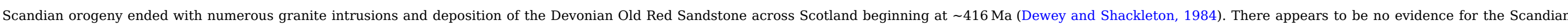

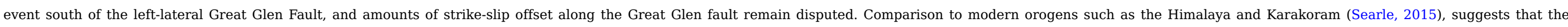
Caledonian orogeny may have been one continuous, possibly pulsed, metamorphic episode that lasted for

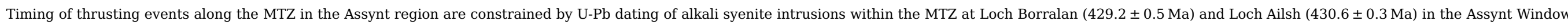

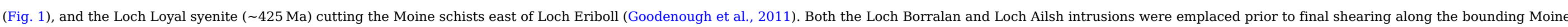

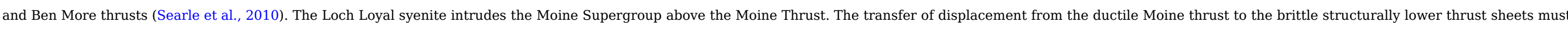

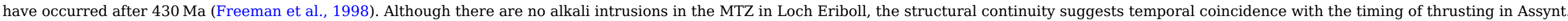

\section{3. $\underline{3}$ Tectono-stratigraphic units}

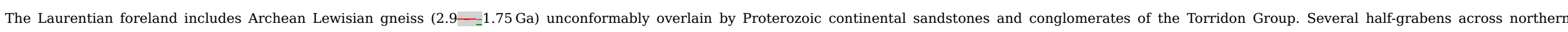

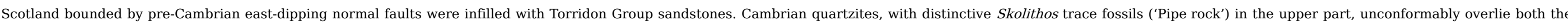

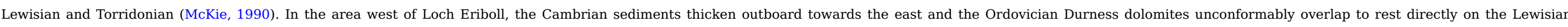

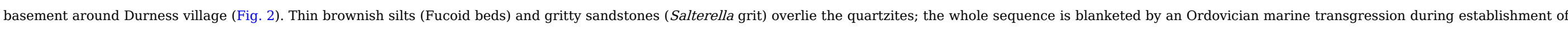

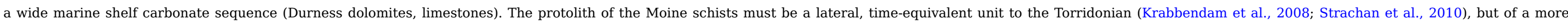

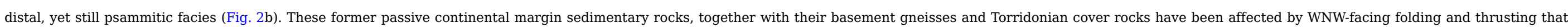
has occurred along at least four major thrust sheets.

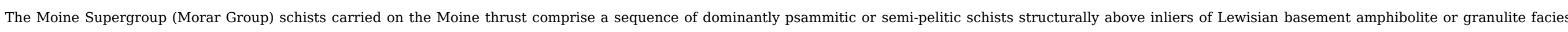

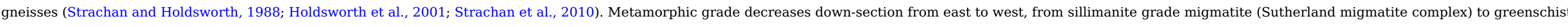

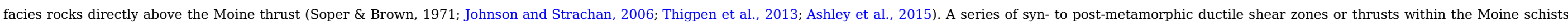
(Skinsdale, Sgurr Beag, Naver, Ben Hope thrusts from upper to lower) place higher grade rocks onto lower grade rocks.

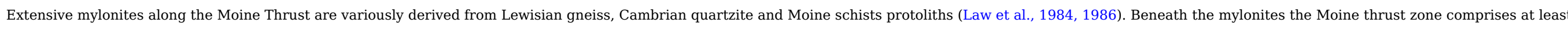

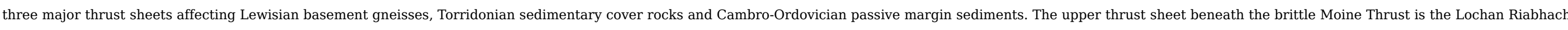

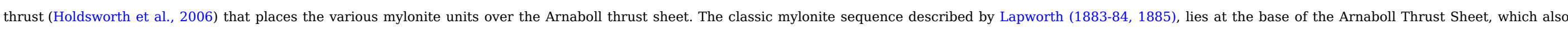
comprises Lewisian basement gneisses and Cambro-Ordovician cover. The Arnaboll thrust placed these rocks over the intensely imbricated Cambro-Ordovician sedimentary rocks of the Sole thrust sheet. 


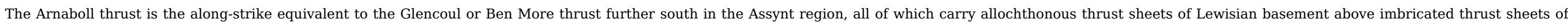

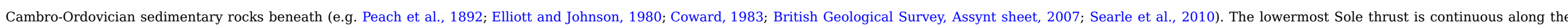
length of the Moine thrust zone and forms the basal detachment above the stable foreland to the west.

\section{4. $\underline{4}$ Moine thrust sheet}

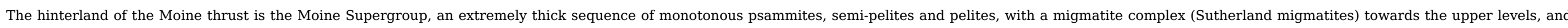

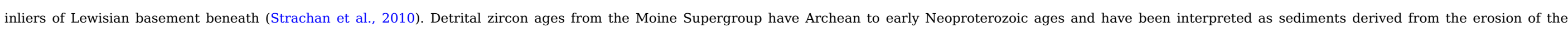

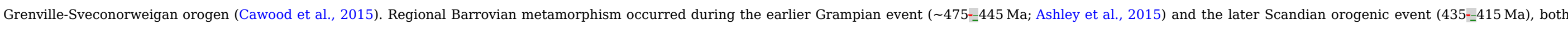

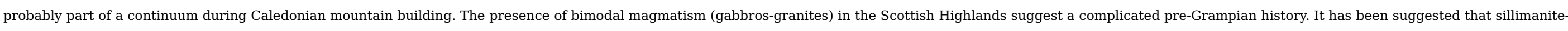

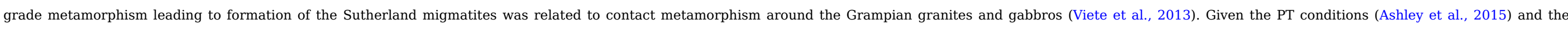

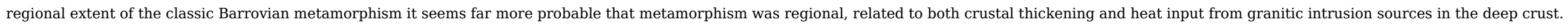

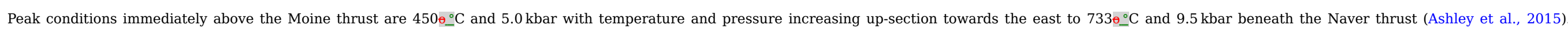

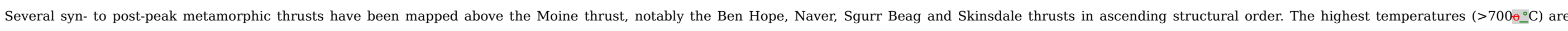

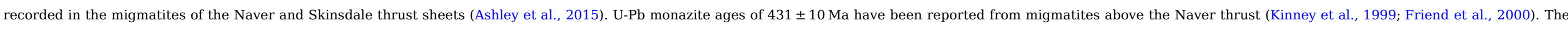

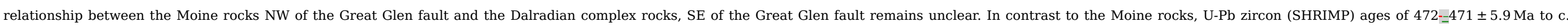
465 Ma are reported for peak metamorphism from the Dalradian complex SE of the Great Glen (Oliver et al., 2000; Viete et al., 2013).

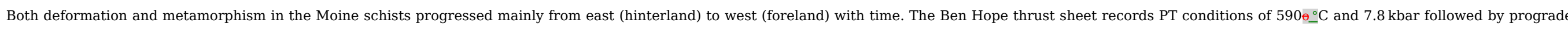

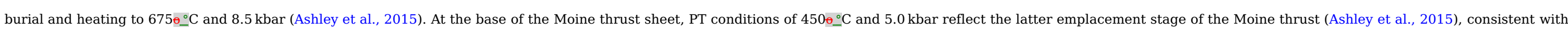

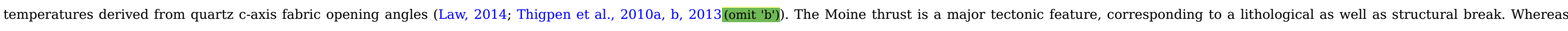

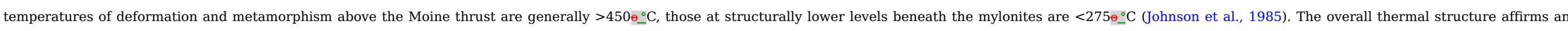

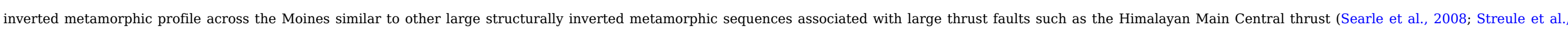
2010).

\section{5.}

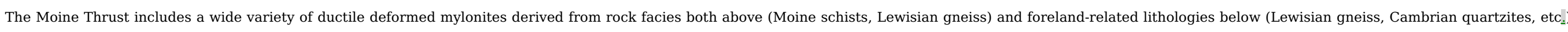

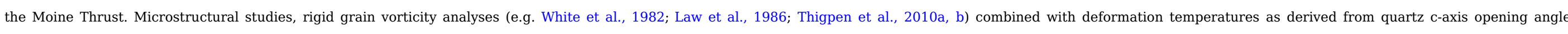

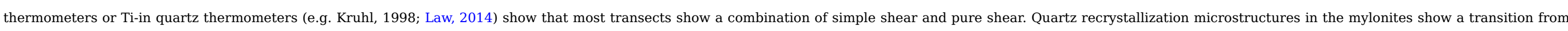

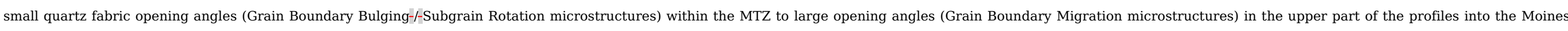
(Law, 2014). Complex changes in deformation temperatures across shear zones, strain rate and fluid (water) weakening all affect the recrystallization microstructures.

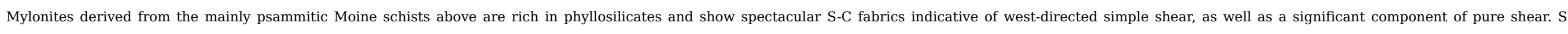

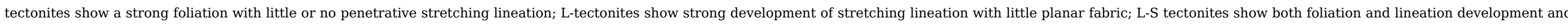

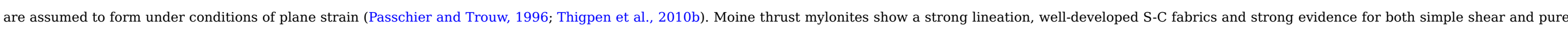

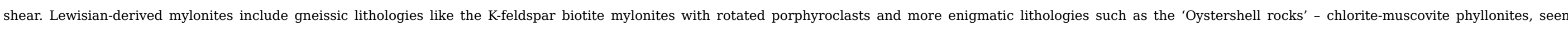

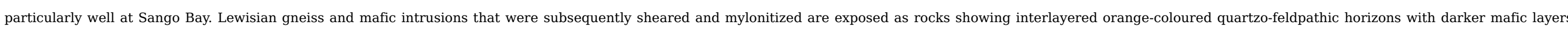

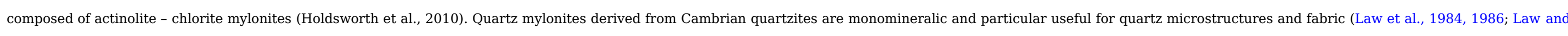
Johnson, 2010).

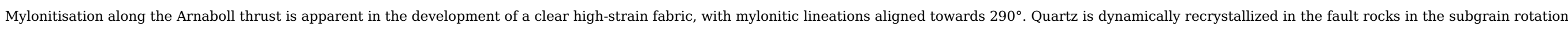




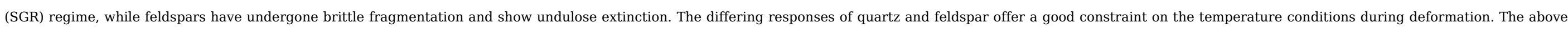

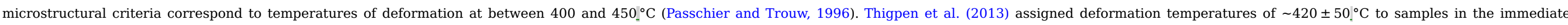
hangingwall of the Moine thrust to the NE of Loch Eriboll, which originated at similar depths to the Arnaboll mylonites.

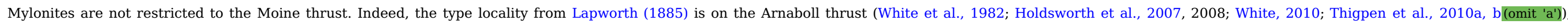

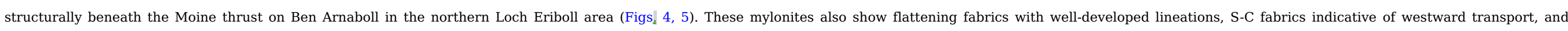

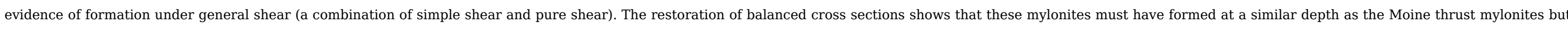
in a more foreland position. It is likely that all the deeper hinterland thrusts bearing mylonites initiated from a similar depth.

\section{6. $\underline{6}$ Position of the Moine thrust}

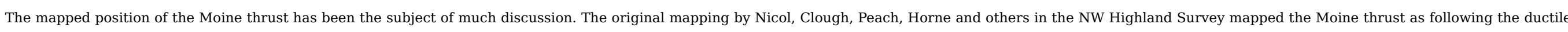

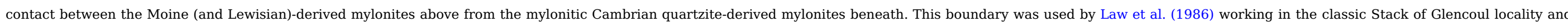

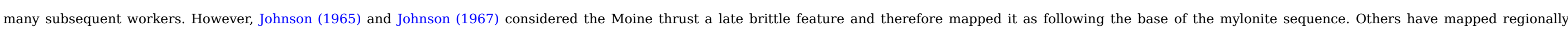

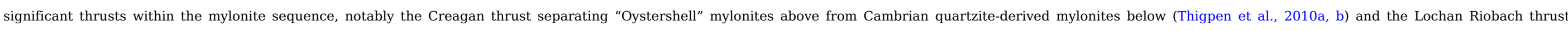
separating Lewisian mylonites above from imbricated unmylonisited rocks of the Arnaboll thrust sheet below (Holdsworth et al., 2006).

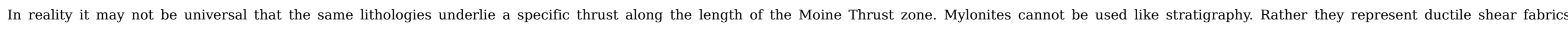

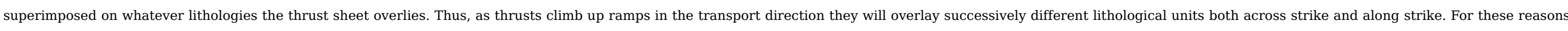

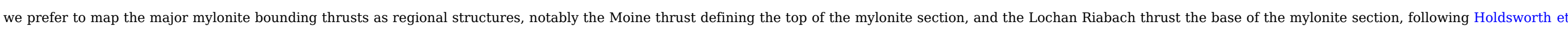
al. (2006). Inter-mylonite thrusts, such as the Creagan thrust (Thigpen et al., 2010a, b) may vary along strike as thrusts are progressively following flats and ramps over different footwall units.

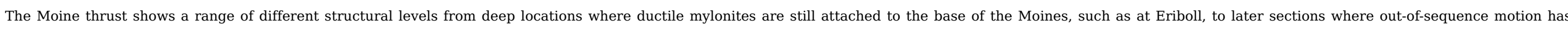
resulted in mylonites resting almost directly on foreland units, such as at Knockan crag in the southern Assynt Window (Elliott and Johnson, 1980; British Geological Survey, 2007; Searle et al., 2010).

\section{7.. Arnaboll thrust sheet}

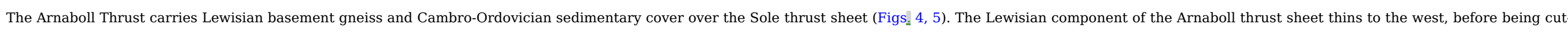

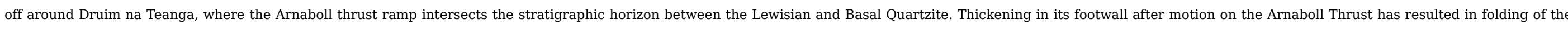

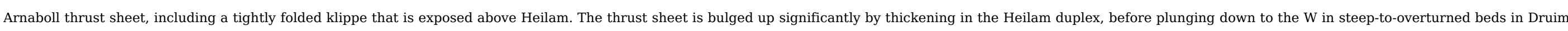

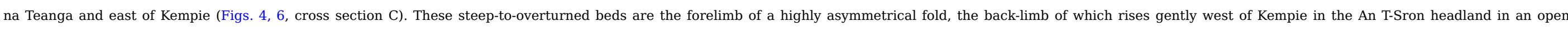
antiform (Figs. 4, 6)

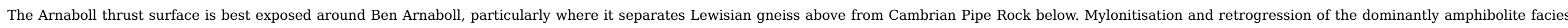

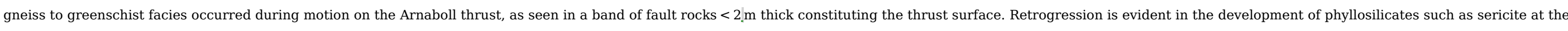

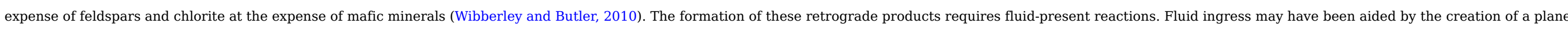
of weakness during faulting, while the creation of weak, hydrous products may have promoted the localisation of strain within the narrow zone of retrogression

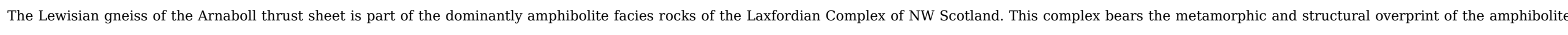

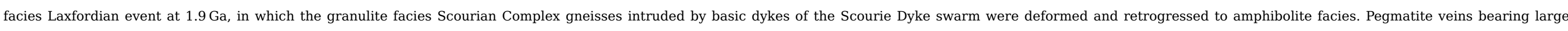

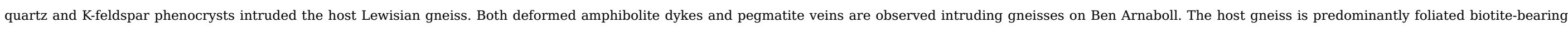
syeno-granite, as well as rocks that show a mix of mafic and felsic constituents in strongly gneissic bands.

\subsection{Sole Tthrust sheet}




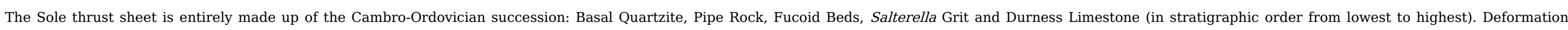
within this tectonic unit was thin-skinned and occurred in the brittle regime; faulting is generally localised onto discrete planes, with cataclasis occasionally apparent in the surrounding few metrers of rock.

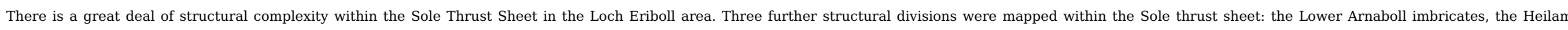
Duplex and the Lighthouse Duplex (as defined in Coward, 1984).

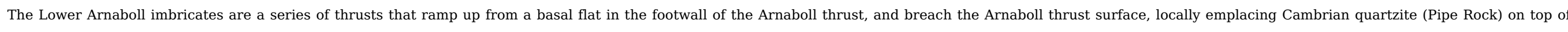

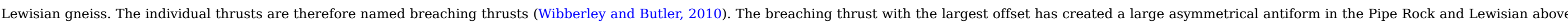

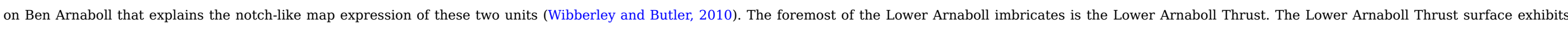

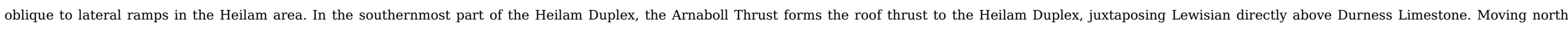

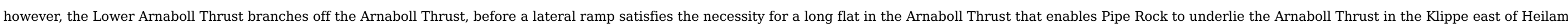
Cottage (Figs. 4, 7, 8).

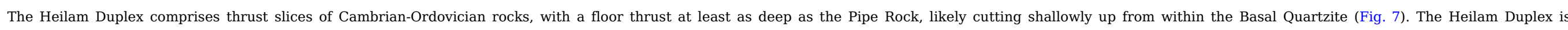

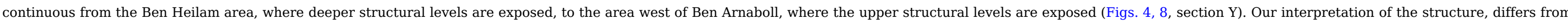

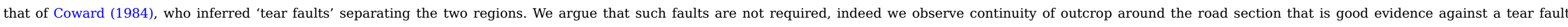
solution (Fig. 4).

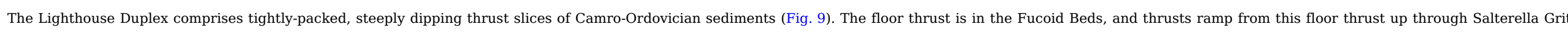

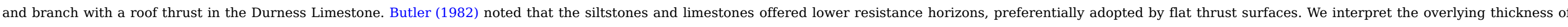

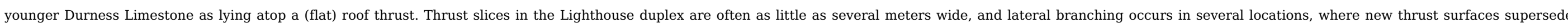

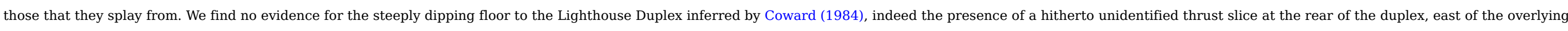

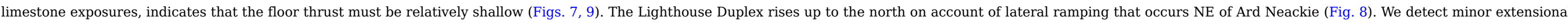
faulting in the hangingwall overlying the lateral ramps, consistent with the geometrical expectation that some thinning should occur above the ramps to conserve volume.

\subsection{Devonian and Permian-Triassic normal faulting}

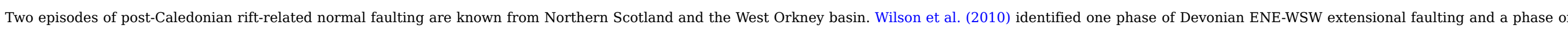

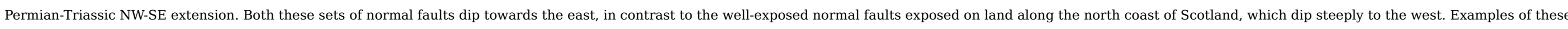

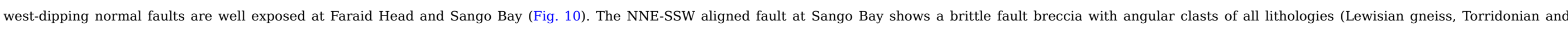
Cambrian sandstones, Durness limestone), including mylonites in a red oxidised-Fe sandy matrix.

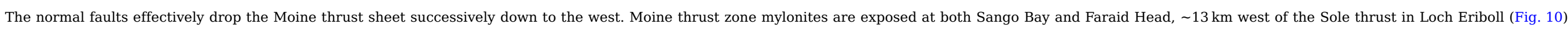

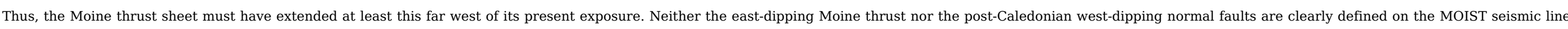
(see section below).

\subsection{Lithospheric structure}

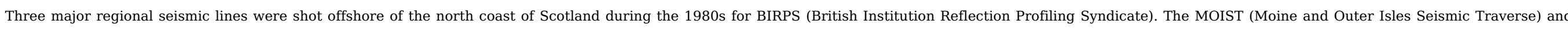

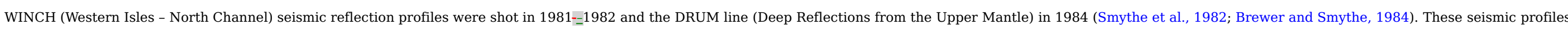

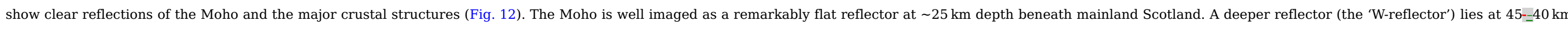
depth within the upper mantle (Snyder et al., 1997), although it is unclear precisely what this seismically reflective horizon represents.

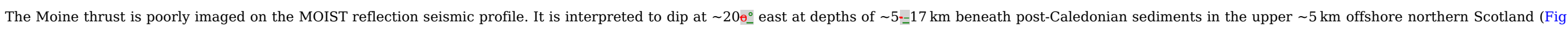




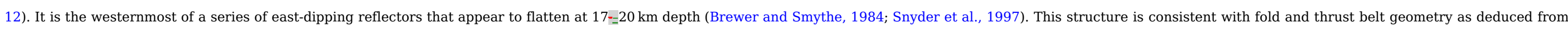

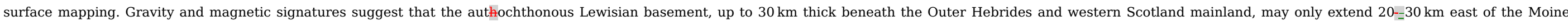

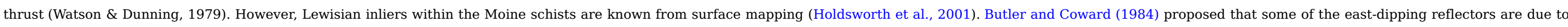
imbrication of Lewisian basement in crustal-scale duplexes, which would imply Caledonian age crustal thickening of an originally eastward thinning Lewisian basement.

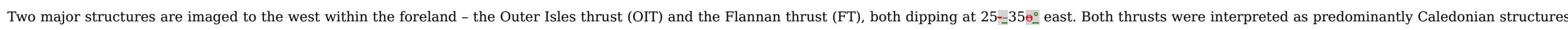

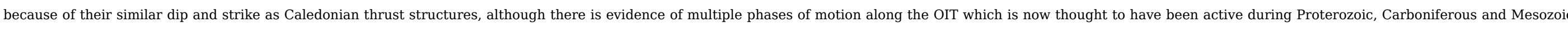

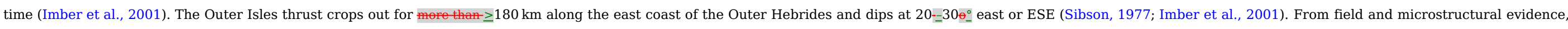

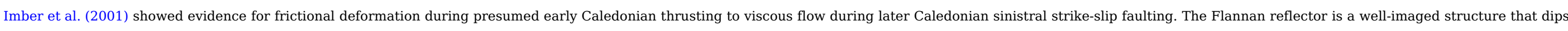

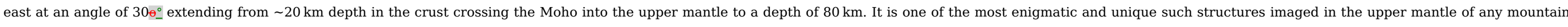
belt, and precisely what structure it is, remains uncertain. Interpretation of the MOIST seismic reflection profile suggests that the fault cuts and offsets the Moho at $>25 \mathrm{~km}$ depth (Smythe et al., 1982 ).

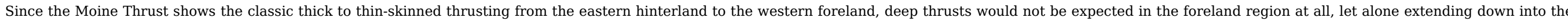

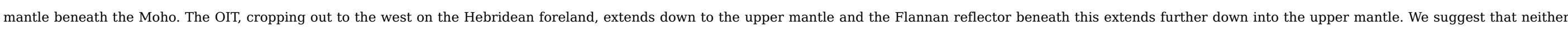

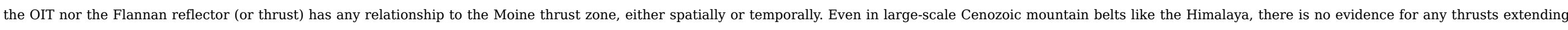

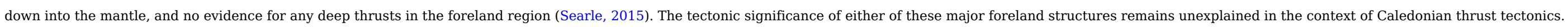

\subsection{Discussion: evolution of the Moine Tthrust zone 11.1.11.1 Thrust geometry and propagation}

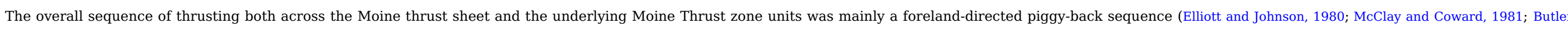

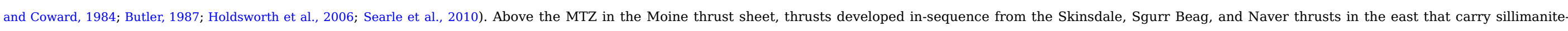

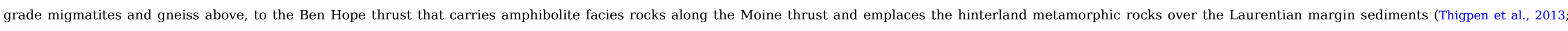

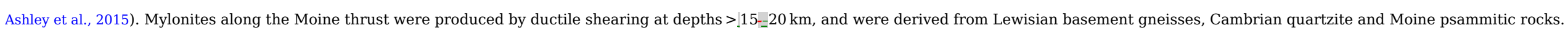

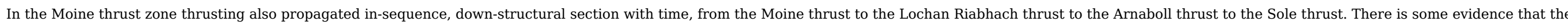

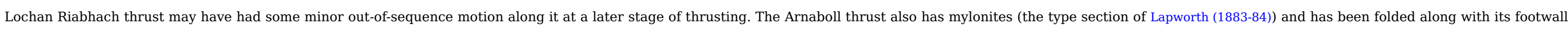

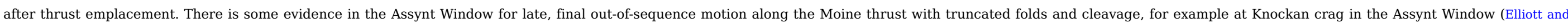

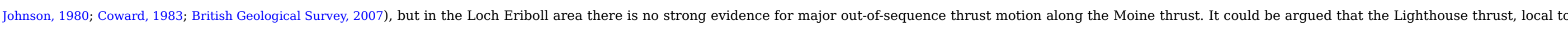

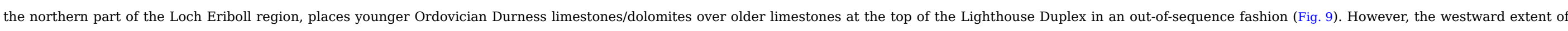

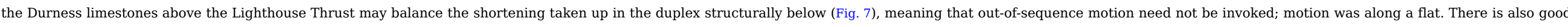
evidence of late breakback thrusting along the steeply-inclined Teanga thrust (Coward, 1984) that cuts the Sole and Arnaboll duplexes, uplifting the hangingwall by $\sim 100$-metersm (Figs 4 4, 6, 7).

\subsubsection{Shortening estimates}

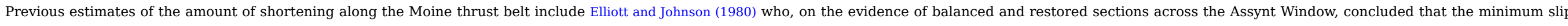

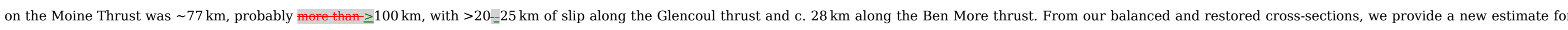

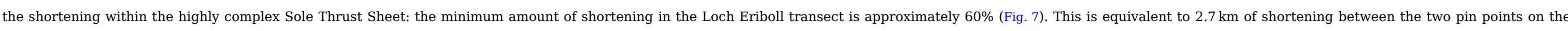

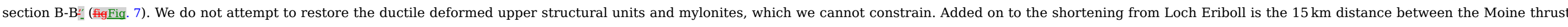
at Loch Eriboll and the western extent at Faraid Head, where it has been downthrown to the west along several post-Caledonian normal faults (Fig. 10).

\subsubsection{Restoration of the Caledonian thrust sheets}




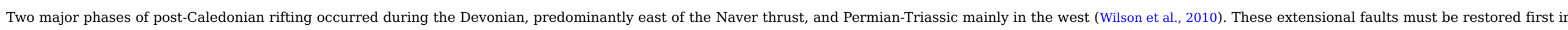

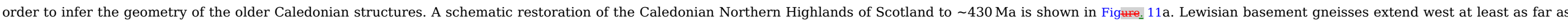

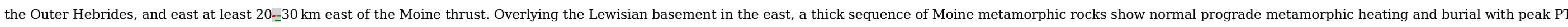

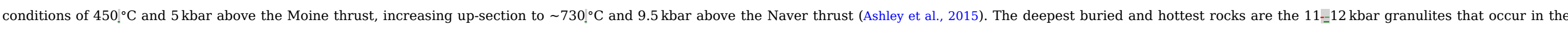

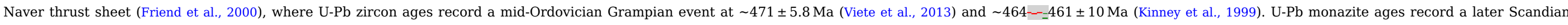

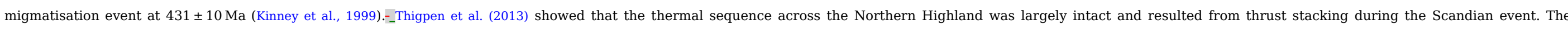

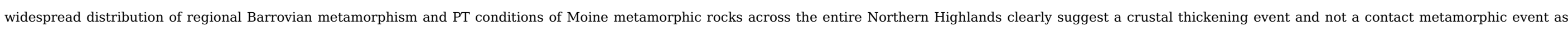
suggested by Viete et al. (2013). The highest levels of the Moine series in northeast Scotland the deformed Strath Halladale granite has a U-Pb monazite of $426 \pm 2$ Ma (Kocks et al., 2006).
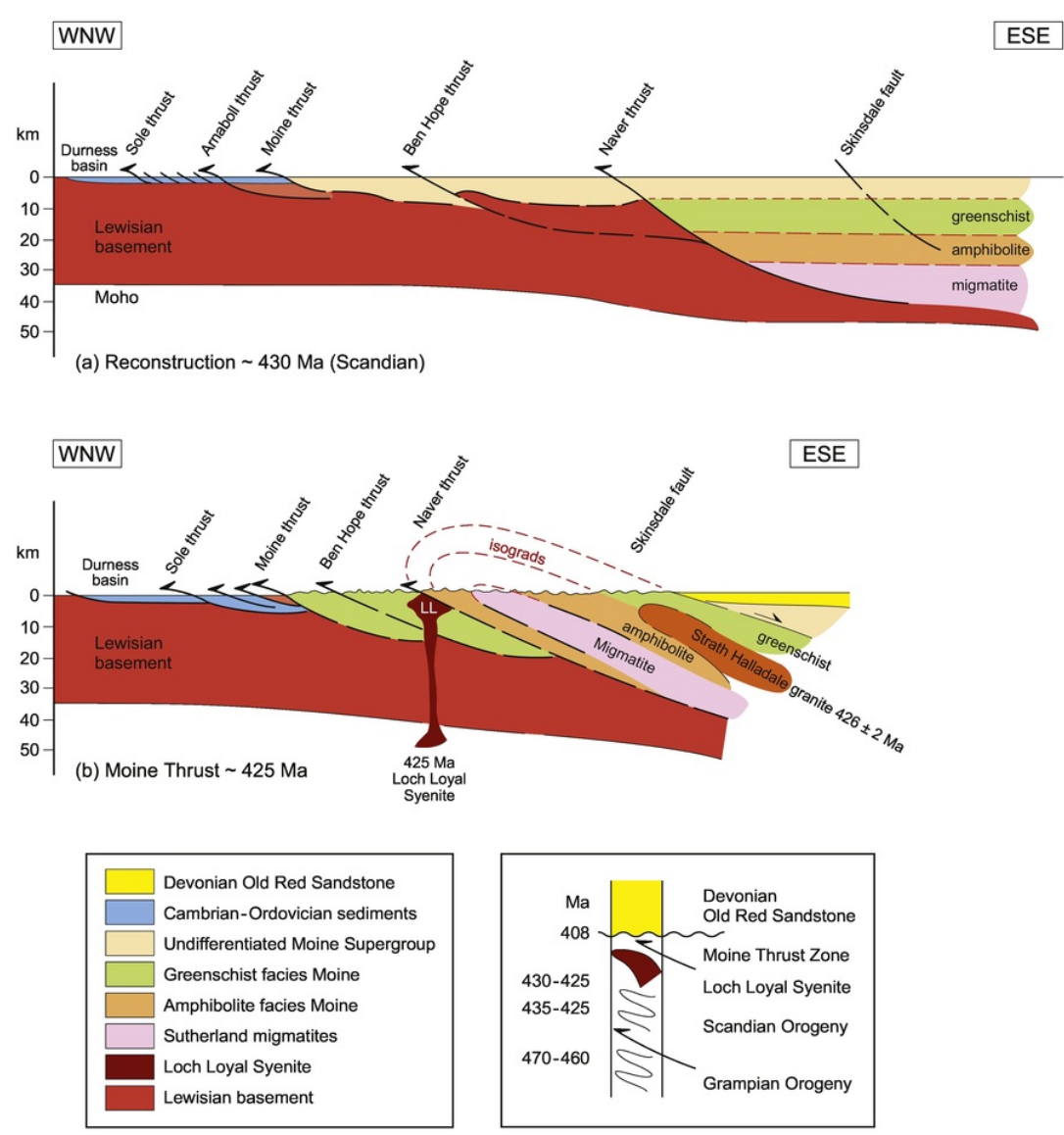

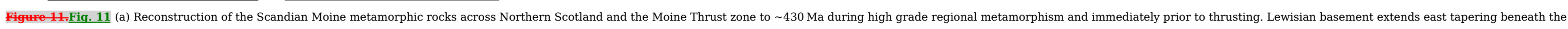

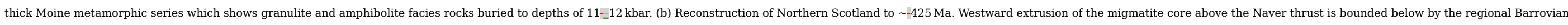

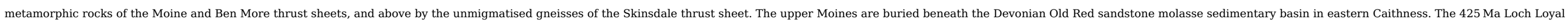
syenite intruded up from mantle depths to its present position in the Ben Hope thrust sheet.

\section{alt-text: Fig. 11}



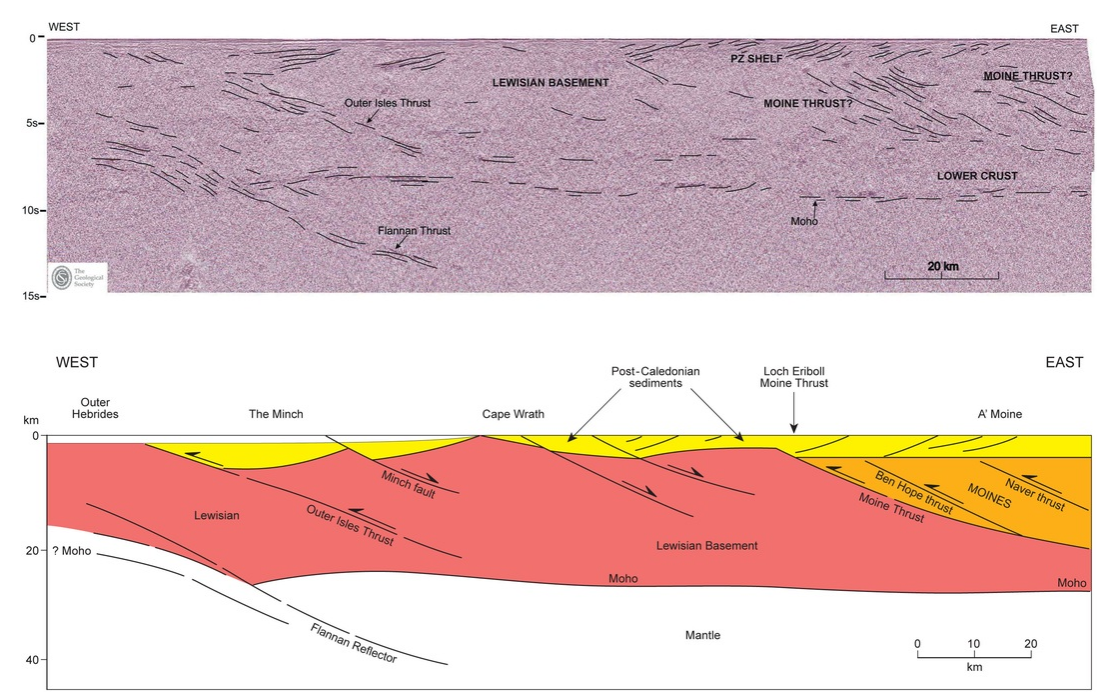

Figure 12.Fig. 12 (a) The MOIST seismic profile across offshore Northwest Scotland, after Snyder et al. (1997), courtesy of the Geological Society, London, and (b) our geological interpretation of the lithospheric profile. alt-text: Fig. 12

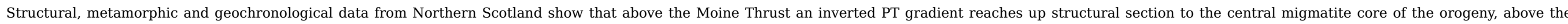

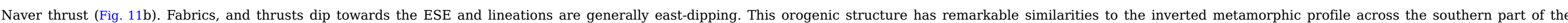

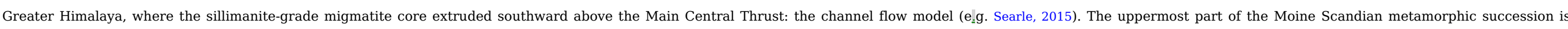

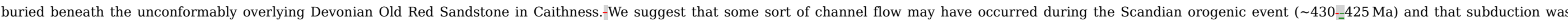

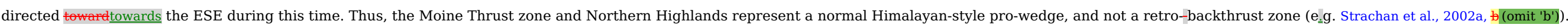

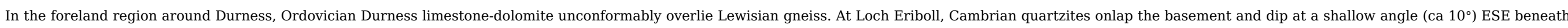

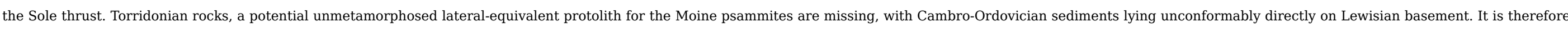

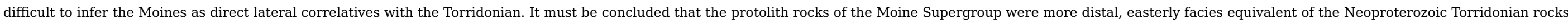
(Fig. 2a).

\subsection{Conclusions}

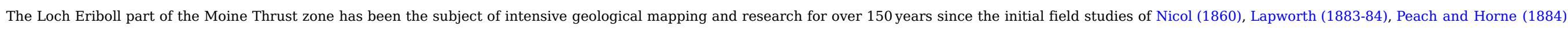

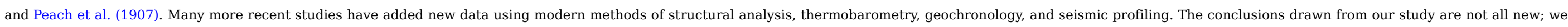
integrate new findings from detailed field mapping and our review of the literature, with the most pertinent conclusions from previous work. Our conclusions can be summarised as follows:-

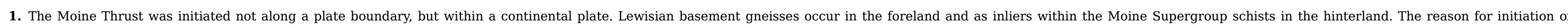

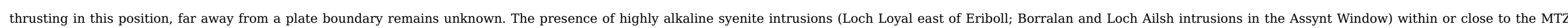
might suggest an anomalously hot sub-continental mantle might have triggered thrusting.

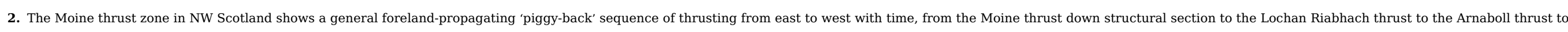
the Sole thrust (Elliott and Johnson, 1980; Butler and Coward, 1984; Butler, 1987; Coward, 1988; Holdsworth et al., 2007).

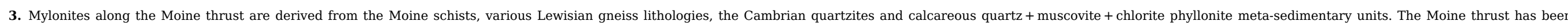




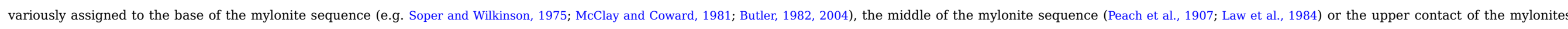
(Holdsworth et al., 2006). Confusion in nomenclature arises because thrusts cut differing lithologies both across strike as they climb ramps and along strike, and mylonites cannot be used as a stratigraphic marker.

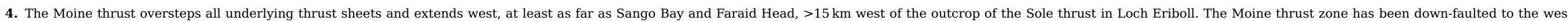
along a series of steep WNW-dipping normal faults, likely of Devonian age, between Loch Eriboll and Sango Bay (Wilson et al., 2010).

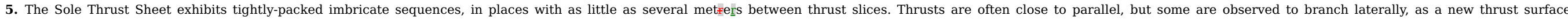

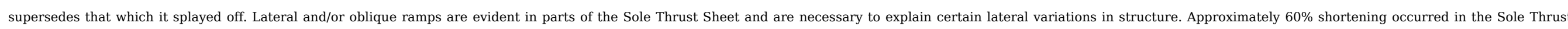
Sheet.

6. The Sole Thrust Sheet includes examples of breaching thrusts, where underlying imbricate thrusts have cut up through the Arnaboll Thrust surface (Butler, 1987; Wibberley and Butler, 2010).

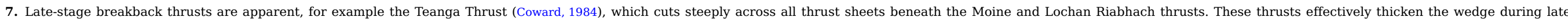
stage (Sole thrust or later) evolution of the thrust belt.

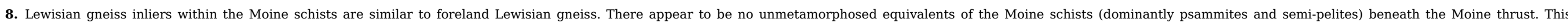

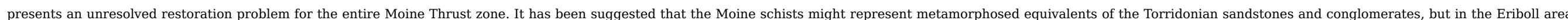
the Cambrian quartzites, thin Fucoid beds, Salteralla grits and Ordovician Durness carbonates lie unconformably above Lewisian gneiss with no intervening Torridonian.

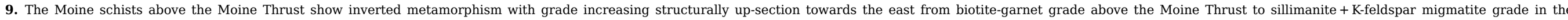

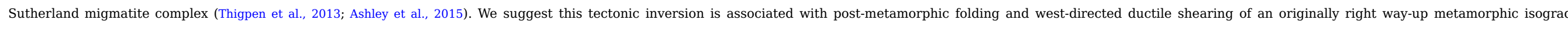
sequence, similar to the Main Central Thrust zone in the Himalaya (Searle et al., 2008; Streule et al., 2010; Searle, 2015).

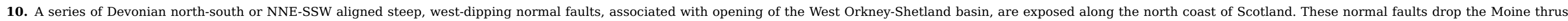

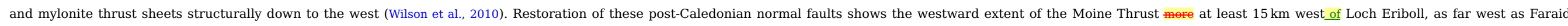
Head.

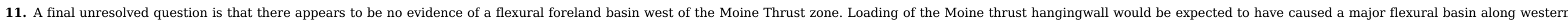

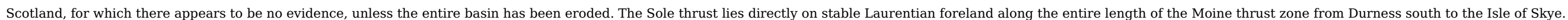

\section{Uncited references}

Butler et al., 2006

Goodenough et al., 2006

Holdsworth, 1989

Holdsworth et al., 1986

\section{Acknowledgements}

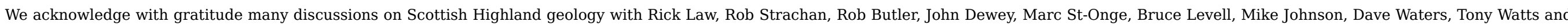

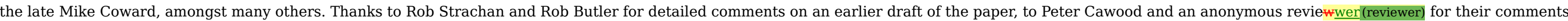
and to Olivier Lacombe for editorial efficiency.

\section{References}

Ashley K.T., Thigpen J.R. and Law R.D., Prograde evolution of the Scottish Caledonides and tectonic implications, Lithos 224-5, 2015, 160-178.

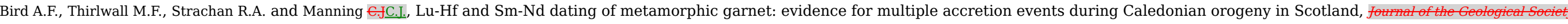


Leol. Soc. Lond. 170, 2013, 301-317, https://doi.org/10.1144/jgs2012-083.

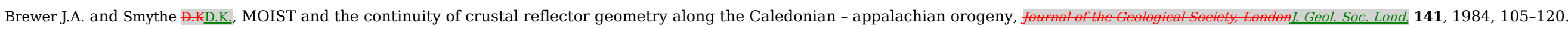
British Geological Survey, Loch Eriboll Sheet, Scale 1:50,000, 2002, British Geological Survey; Keyworth, Nottingham.

British Geological Survey, Assynt, Scotland; Special Sheet, Bedrock, Scale: 1:50,000 Geology Series, 2007, British Geological Survey; Keyworth, Nottingham.

Butler R.W.H., A structural analysis of the Moine thrust zone between Loch Eriboll and Foinaven, NW Scotland, foumal of Struetural Geologyj. Struct. Geol. 4, 1982, 19-29.

Butler R.W.H., Thrust sequences, J. Geol. Soc. Lond. 144, 1987, 619-634.

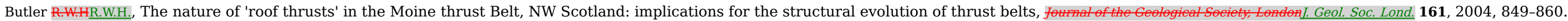

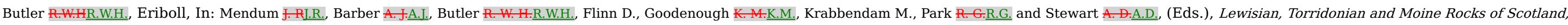

Geological Conservation Review Series vol. 34, 2009, Joint Nature Conservation Committee; Peterborough, 721.

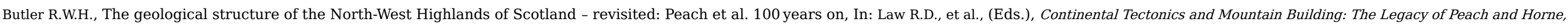
335, 2010a, Geological Society, London Special Publication, 7-27, https://doi.org/10.1144/SP335.2.

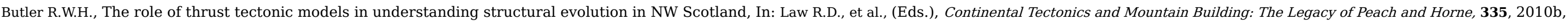
Geological Society, London Special Publication, 293-320, https://doi.org/10.1144/SP335.14.

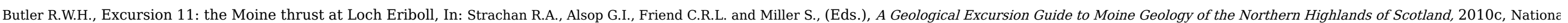
Museums of Scotland, 191-216.

Butler R.W.H. and Coward M.P., Geological constraints, structural evolution and deep geology of the northwest Scottish Caledonides, Tectonics 3, 1984 , 347-365.

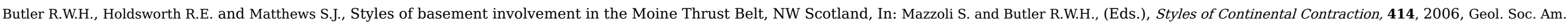
Spec. Pap., 133-151.

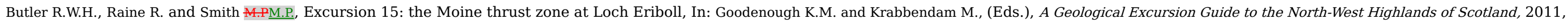

National Museums of Scotland, 181-197.

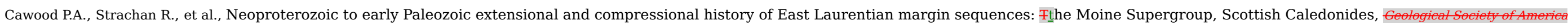
BulletimGeol. Soc. Am. Bull. 127, 2015, 349-371, https://doi.org/10.1130/B31068.1.

Coward M.P.M.P., The thrust and shear zones of the Moine thrust zone and NW Scottish Caledonides, fournal of the Geological Society of London]. Geol. Soc. Lond. 140, 1983 , 795-811.

Coward M.P., A geometrical study of the Arnaboll and Heilam thrust sheets, NW of Ben Arnaboll, Sutherland, Seottish Joural of Geogy Scott. Jeol. 20, 1984, 87-106.

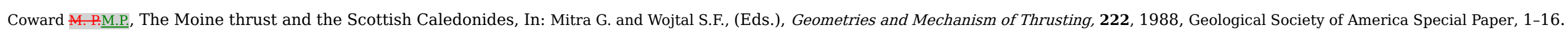

Dewey J.F. and Shackleton R.J., A model for the evolution of the Grampian tract in the early Caledonides and Appalachians, Nature, LondonNature (London) 148, 1984, 137-180.

Dewey J.F. and Strachan R.A., Changing Silurian-Devonian relative plate motion in the Caledonides: sinistral transpression to sinistral transtension, J. Geol. Soc. Lond. 160, 2003, 219-229.

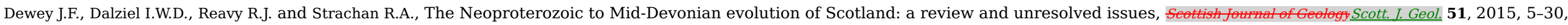

https://doi.org/10.1144/sjg2014-007.

Elliott D. and Johnson M.R.W., The structural evolution of the northern part of the Moine thrust zone, Trans. Roy. Soc. Edinb. Earth Sci. 71, 1980, 69-96. 


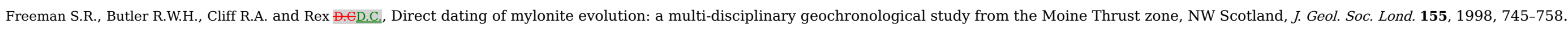

Friend C.R.L., Jones K.A. and Burns F.MI.M., New high-pressure event in the Moine Supergroup, northern Scotland: implications for Taconic crustal evolution, Geology 28, 2000, 543-546.

Geikie AA., The crystalline schists of the Scottish Highlands, Nature 31, 1884, 29-31.

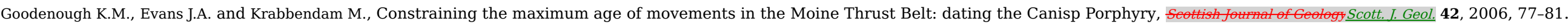

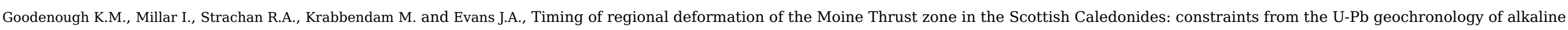

intrusions, J. Geol. Soc. Lond. 168, 2011, 99-114, https://doi.org/10.1144/0016-76492010-020.

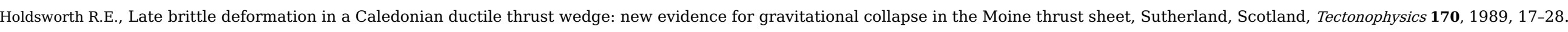

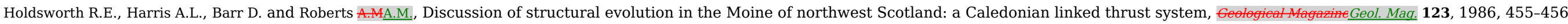

Holdsworth R.E., Strachan R.A. and Alsop G.I., Geology of the Tongue District. Memoir of the British Geological Survey. HMSO, 2001.

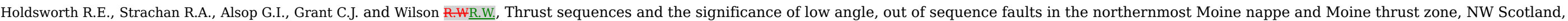
Geol. Soc. Lond. 163, 2006, 801-814.

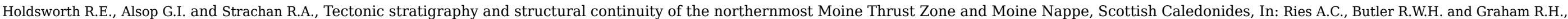
(Eds.), Deformation of the Continental Crust: The Legacy of Mike Coward, 272, 2007, Geological Society, London Special Publications, 121-142.

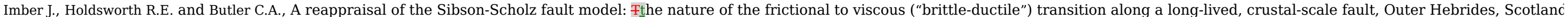
Tectonics 20, 2001, 601-624.

Johnson M.R.W., The Moine Thrust zone: a discussion, foumal of GeologyJ. Geol. 100, 1965, 417-432.

Johnson M.R.W., Mylonite zones and mylonite banding, Nature 213, 1967, 246-247.

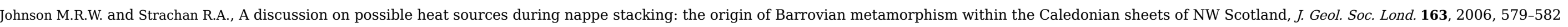

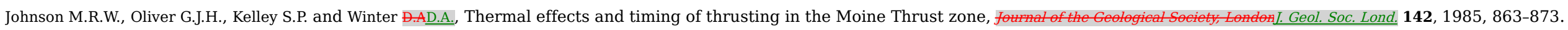

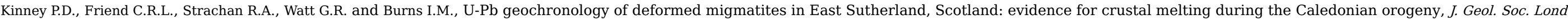
156, 1999, 1143-1152.

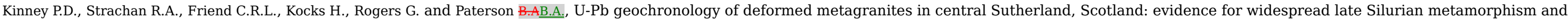
ductile deformation of the Moine Supergroup during the Caledonian orogeny,

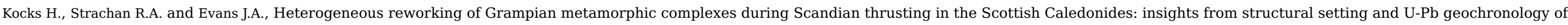
the Strath Hallidale granite, J. Geol. Soc. Lond. 163, 2006, 525-538.

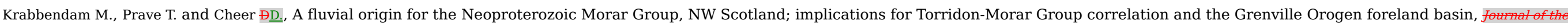

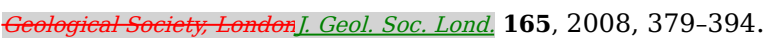

Lapworth C., On the structure and metamorphism of the rocks of the Durness-Eriboll district, Proc. Geol. Assoc. 8, 1883-84, 438-442.

Lapworth $\in$ C., On the close of the Highland controversy, Geological MagazineGeol. Mag. 2, 1885, 97-106.

Law R.D., Deformation thermometry based on quartz c-axis fabrics and recrystallization microstructures: a review, foural of Stretural Geoloct I. Struct. Geol. 66, 2014 , $129-161$. 


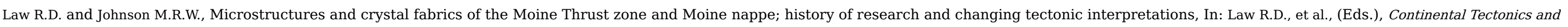
Mountain Building, The Legacy of Peach and Horne, 335, 2010, Geological Society, London, Special Publication, 443-503.

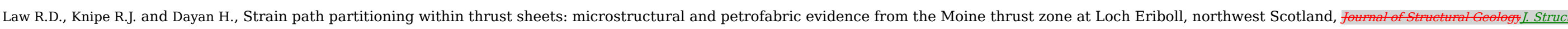
Geol. 6, 1984, 477-497.

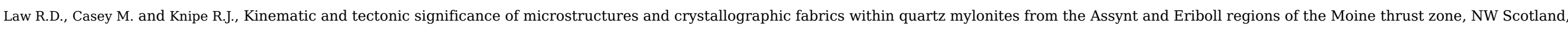
Transactions of the Royal Society of Edinburgh: Earth Seiencestrans. R. Soc. Edinb. Earth Sci. 77, 1986, 99-126.

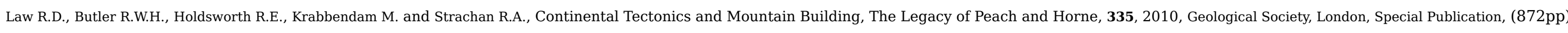

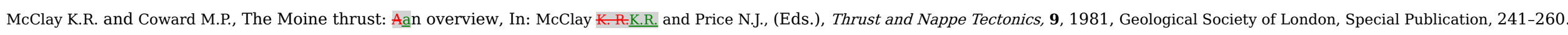

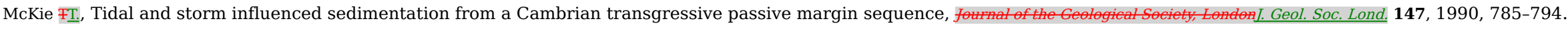

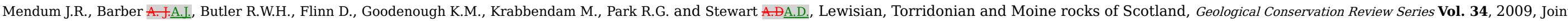
Nature Conservation Committee; Peterborough.

Nicol JI, On the structure of the NW Highlands and the relationship of the gneiss, red sandstone and quartzite of Sutherland and Ross-shire, Q. J. Geol. Soc. Lond. 17, 1860, 85-113.

Oliver G.J.H., Chen FF. and Buchwaldt R., Fast tectonometamorphism and exhumation in the type area of the Barrovian and Buchan zones, Geology 28, $2000,459-462$.

Passchier C.W. and Trouw R.A.J., Microtectonics, 1996, Springer, (289p).

Peach B.N. and Horne 玵, Report on the geology of northwest Scotland, Nature 31, 1884, 31-35.

Peach B.N., Horne J., Clough C.T., Hinxman L.W., Cadell H.M. and Dinham E.HC.H., Assynt District. Scale 1:50,000, Ordnance Survey of Great Brita, 1892.

Peach B.N., Horne J., Gunn W., Clough C.T. and Hinxman L.W., The Geological Structure of the Northwest Highlands of Scotland: Memoir of the Geological Survey of Great Britain, 1907.

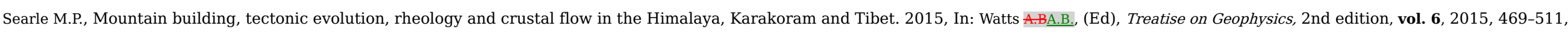

https://doi.org/10.1016/B978-0-444-53802-4.001221-4.

Searle M.P., Law R.D., Godin L., Larsen K.P., Streule M.J., Cottle J.M. and Jessup M.J., Defining the Himalayan Main Central Thrust in Nepal, J. Geol. Soc. Lond. 164, 2008 , 523-534.

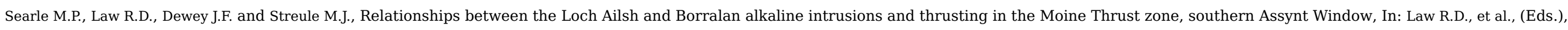

Continental Tectonics and Mountain Building: The Legacy of Peach and Horne, 335, 2010, Geological Society, London Special Publication, 383-404, https://doi.org/10.1144/SP335.18.

Sibson R.HR.H., Fault rocks and fault mechanisms, J. Geol. Soc. Lond. 133, 1977, 191-213.

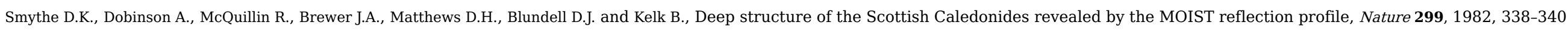

Snyder D.B., England R.W. and McBride J.H., Linkage between mantle and crustal structures in northwester Scotland, J. Geol. Soc. Lond. 154, 1997, 79-84.

Soper N.J. and Wilkinson P., The Moine thrust and Moine Nappe at Loch Eriboll, Sutherland, seottish Joumal of Geology Scott. J. Geol. 11, 1975, 339-359.

Strachan R.A. and Holdsworth R.E., Basement-cover relationships and structure within the Moine rocks of central and southeast Sutherland, J. Geol. Soc. Lond. 145, 1988, 23-36.

Strachan R.A., Harris A.L., Fettes D.J. and Smith M., The Highland and Grampian terranes, In: Trewin N.H., (Ed), The Geology of Scotland, 2002a, The Geological Society; London, 81-148.

Strachan R.A., Holdsworth R.E., Alsop G.I., McErlean M.A. and Burns I.M., Loch Eriboll (Sheet 114W, Solid) British Geological Survey 1:50,000 Map Sheet, 2002b. 


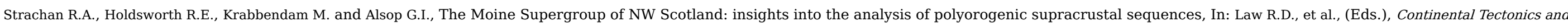
Mountain Building: The Legacy of Peach and Horne, 335, 2010, Geological Society, London Special Publication, 231-252, https://doi.org/10.1144/SP335.11.

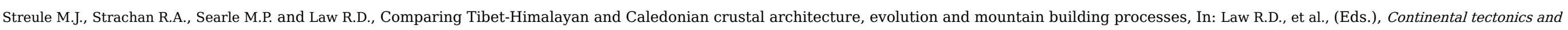
Mountain Building: The Legacy of Peach and Horne, 335, 2010, Geological Society, London Special Publication, 207-232, https://doi.org/10.1144/SP335.10.

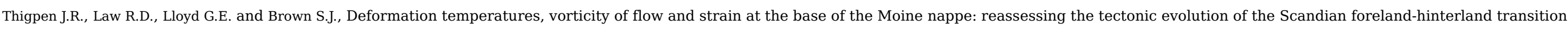
zone, foumal of Structural GologyJ. Struct. Geol. 21, 2010a, 920-940.

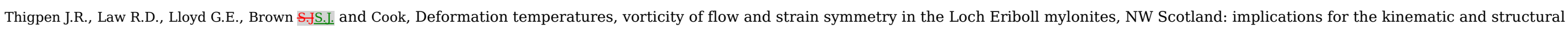

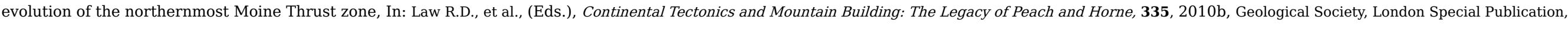
623-662, https://doi.org/10.1144/SP335.26.

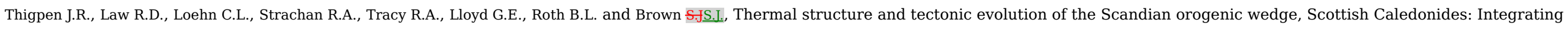
geothermometry, deformation temperatures and kinematic thermal modelling, Getamorph. Geol. 31, 2013, 813-842.

Viete D.R., Oliver G.J.H., Fraser G.L., Forster M.A. and Lister G.S., Timing and heat sources for the Barrovian metamorphism, Scotland, Lithos 177, 2013 , 148-163.

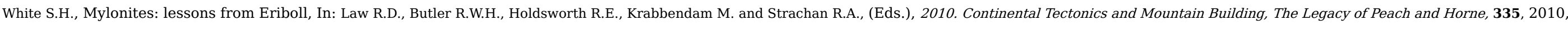
Geological Society, London, Special Publication, 505-542.

White S.H., Evans D.J. and Zhong D.L., Fault rocks in the Moine Thrust Zone: microstructures and textures of selected mylonites, Textures Microstruct. 5, 1982 , 33-61.

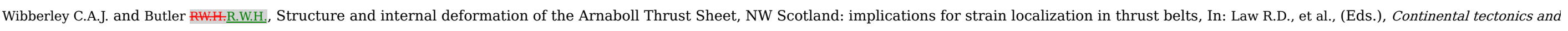
Mountain Building: The Legacy of Peach and Horne, 335, 2010, Geological Society, London Special Publication, 321-333, https://doi.org/10.1144/SP335.15.

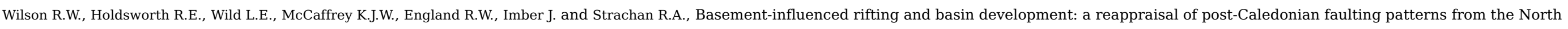

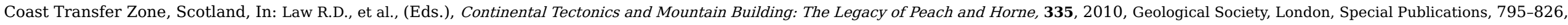
https://doi.org/10.1144/SP335.32 0305-8719/10.

Woodcock N. and Strachan R.A., Geological History of Britain and Ireland, 2000, Blackwells.

\section{Highlights}

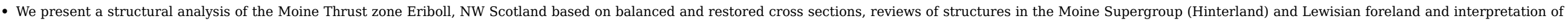
deep seismic lines offshore NW Scotland.

\section{Queries and Answers}

\section{Query:}

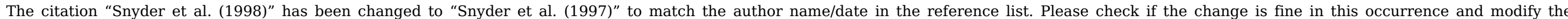
subsequent occurrences, if necessary. 
Answer: OK

Query:

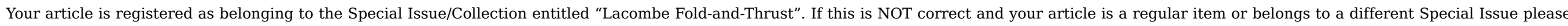
contact d.perumal@elsevier.com immediately prior to returning your corrections.

Answer: Yes - this is the correct special issue

Query:

Please confirm that given names and surnames have been identified correctly and are presented in the desired order, and please carefully verify the spelling of all authors' names.

Answer: Yes

Query:

The author names have been tagged as given names and surnames (surnames are highlighted in teal color). Please confirm if they have been identified correctly.

Answer: Yes

Query:

The country name "United Kingdom of Great Britain and Northern Ireland" has been inserted for the authors' affiliation. Please check, and correct if necessary.

Answer: United Kingdom usually suffices, but we don't mind

Query:

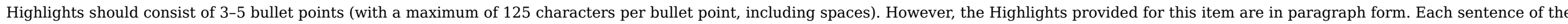

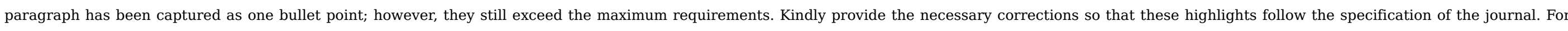
more information, please see the Guide for Authors.

Answer: We present new detailed mapping, together with cross-, lateral-, and restored-sections from the northern Moine Thrust zone

Restoration shows that the intensely deformed Sole Thrust Sheet experienced c. $60 \%$ shortening at Loch Eriboll

We place this mapping in its regional context and review the structural evolution of the northern Moine Thrust Zone

We review orogen wide data from the Moine Thrust hinterland and compare with Himalayan tectonic architecture

Attachments: Highlights.docx

\section{Query:}

Citation "Peach et al., 1888" has not been found in the reference list. Please supply full details for this reference.

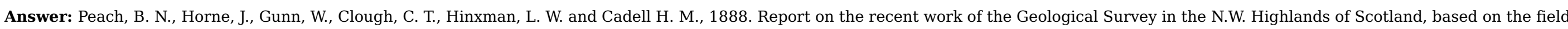
notes and maps. Quarterly Journal of the Geological Society, London, 64, 378-441.

\section{Query:}

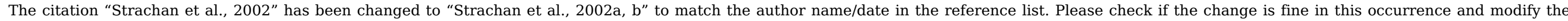
subsequent occurrences, if necessary. 
Answer: omit 'a'

Query:

Citation "Callaway, 1883" has not been found in the reference list. Please supply full details for this reference.

Answer: Callaway, C., 1883. The age of the newer gneissose rocks of the northern Highlands. Quarterly Journal of the Geological Society, London, 39,355-422.

Query:

Citation "Peach et al., 1888" has not been found in the reference list. Please supply full details for this reference.

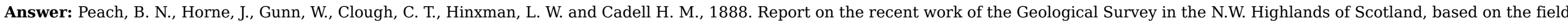
notes and maps. Quarterly Journal of the Geological Society, London, 64, 378-441.

Query:

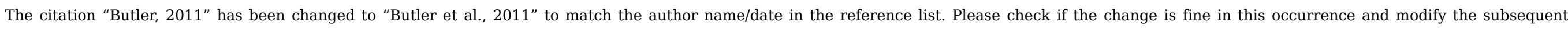
occurrences, if necessary.

Answer: OK

Query:

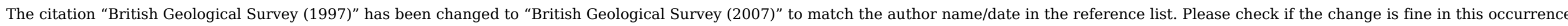
and modify the subsequent occurrences, if necessary.

Answer: OK

Query:

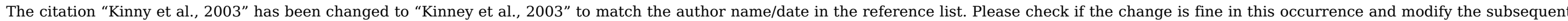
occurrences, if necessary.

Answer: OK

Query:

Citation "Soper \& Brown, 1971" has not been found in the reference list. Please supply full details for this reference.

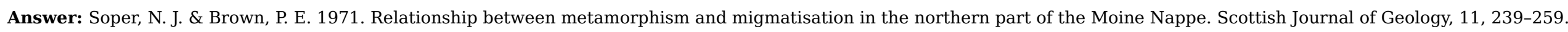

Query:

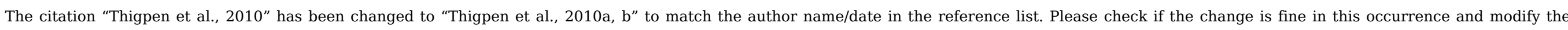
subsequent occurrences, if necessary.

Answer: OK

Query:

Citation "Kruhl, 1998" has not been found in the reference list. Please supply full details for this reference. 


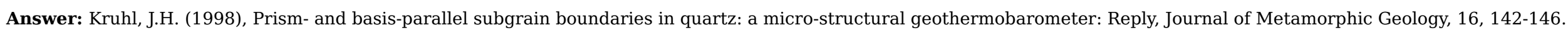

Query:

Citation "Holdsworth et al., 2010" has not been found in the reference list. Please supply full details for this reference.

Answer: please delete 2010 ref

Query:

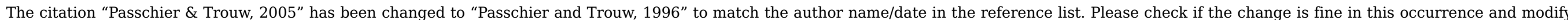
the subsequent occurrences, if necessary.

Answer: OK

Query:

Citation "Holdsworth et al., 2008" has not been found in the reference list. Please supply full details for this reference.

Answer: omit 2008

Query:

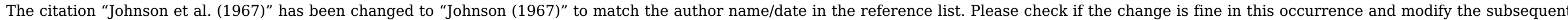
occurrences, if necessary.

Answer: OK

Query:

Citation "Watson \& Dunning, 1979" has not been found in the reference list. Please supply full details for this reference.

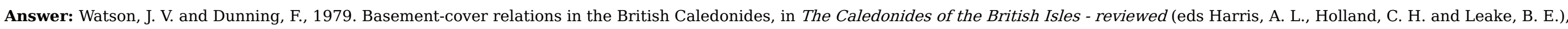
Geological Society of London Special Publications, 8, 67-91.

Query:

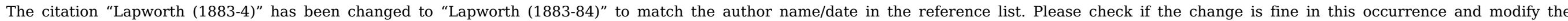
subsequent occurrences, if necessary.

Answer: ok

Query:

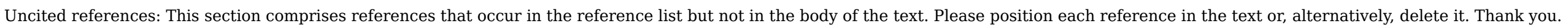

\section{Answer: can all be deleted}

Query:

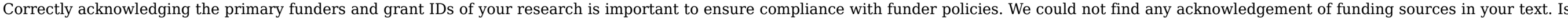
this correct? 


\section{Answer: Yes}

